\title{
الكتابة الحجازية للمصحف الشريف في صدر الإسلام
}

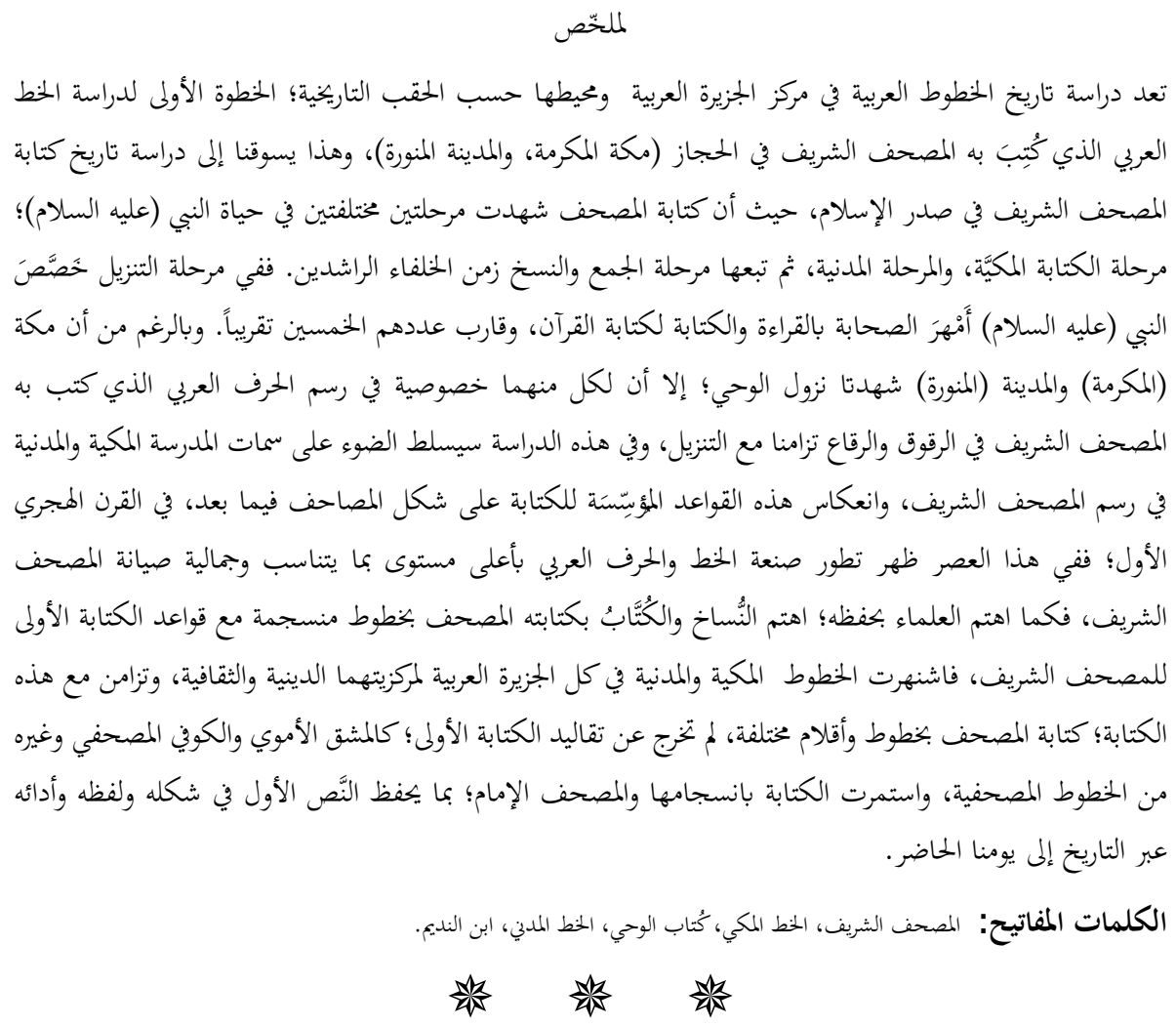

\section{İSLÂM'IN İLK DÖNEMINDE MUȘHAF-I ŞERIFF'IN ḤICÂZÎ YAZISI}

Arap Yarımadası ve çevresinde yürütülen Arap Yazı Tarihi çalışmaları, tarihî dönemler çerçevesinde gerçekleştirilmiştir; bu çalışmaların ilk adımı Hicaz

guller_guler@yahoo.com a أستاذ مشارك ، جامعة اسطنبول، a

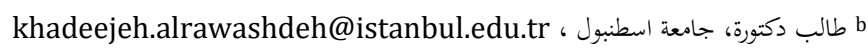


(Mekke-Medine) bölgesine yönelik olmuştur. Bu da araştırmacıları doğal olarak Mushaf yazım çalışmalarına yönlendirmiştir. Efendimiz'in (sav) hayatında Mushaf'ın yazımının iki farklı aşaması olmuştur: Mekke ve Medine aşamaları. Bu aşamalarda vahyin nuzülüne şahitlik eden birçok sahâbî olmasına rağmen Kur'ân'ı okumada ve yazmada maharetli olanların sayısı elli civarındaydı. Ancak nuzül ile birlikte parşömenlere ve çeşitli malzemelere eş zamanlı olarak yazılan Mushaf'taki bu iki yazı çeşidinin Arap harfleri bünyesinde farklı özellikleri bulunmaktaydı. Bu çalışmada, Mushaf taki Mekkî ve Medenî hattın özelliklerine yoğunlaşılacak, daha sonraları "yazım kurallarına verilen bu özelliklerin Mushaf'ın yazımına yansıması ele alınacaktır.

Hicri birinci asırda hat sanatı ve Arap yazısı Mushaf ın korunmasına yönelik olarak olabilecek en iyi seviyeye ulaşmıştı. Bu, âlimlerin Mushaf'ın korunmasına verdiği önemi de göstermektedir. Müstensihler ve Kâtipler de Mushaf'ın yazımında ilkyazım kurallarıyla uyumlu olmaya önem vermişlerdir. Böylece bu iki yazı çeşidi dinî ve kültürel merkezîlikleri dolayısıyla tüm Arap yarımadasında meşhur olmuştur. Bu hatla eş zamanlı olarak farklı hatlar ve kalemler de gelişmiştir. Ancak ilkyazım kuralları dışına çıkılmamıştır. Tüm bunlara örnek olarak Meşk-i Emevî ve Kûfi-yi Mushafî yazı çeşitleri verilebilir. Mushaf yazımı şekliyle, lafzıyla, edasıyla ilk halini muhafaza etmesi için-İmam Mushaf'a uyumla geçmişten günümüze kadar devam etmiştir.

[Geniş Türkçe Öz, çalışmanın sonunda yer almaktadır.]

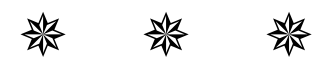

\section{THE HIGAZI SCRIPTURE OF THE HOLY MANUSCRIPT IN THE EARLY TIMES OF ISLAM}

Studying the history of Arabic calligraphy found in the vicinity of the Arabian Peninsula and its development is considered the first step in studying the Arabic calligraphy in which the Noble Qur'an was written in Hijaz (Mecca and Medina). This leads directly to the history of the writing of the Noble Qur'an at the beginning of Islam, which took place in two distinct phases in the lifetime of the Prophet: Meccan phase and Medinan phase. After the prophet's death, the Qur'anic manuscripts were compiled and collected into one standardized version of the Quran (Uthmanic codex), of which, seven copies were made. During the period of revelation (wahy), approximately 50 of the most skilled companions in reading and writing were chosen by the Prophet as scribes of the revelation. Moreover, though the Prophet received the revelation in both the Meccan and the Medinan periods, there are discernible differences in the script styles for each period. the development of Arabic calligraphy at the highest level commensurate with the beauty of writing the Qur'an. The scribes took care of writing the Qur'an in lines consistent with the rules of the first writing of the 
Qur'an. pronunciation and performance throughout history to the present day. In this paper, these differences will be studied and illustrated. In addition, it will be shown that these original script styles persisted throughout the islamic manuscript history and had a lasting influence on later copies of the Qur'an.

[The Extended Abstract is the end of article.]

\section{然溫}

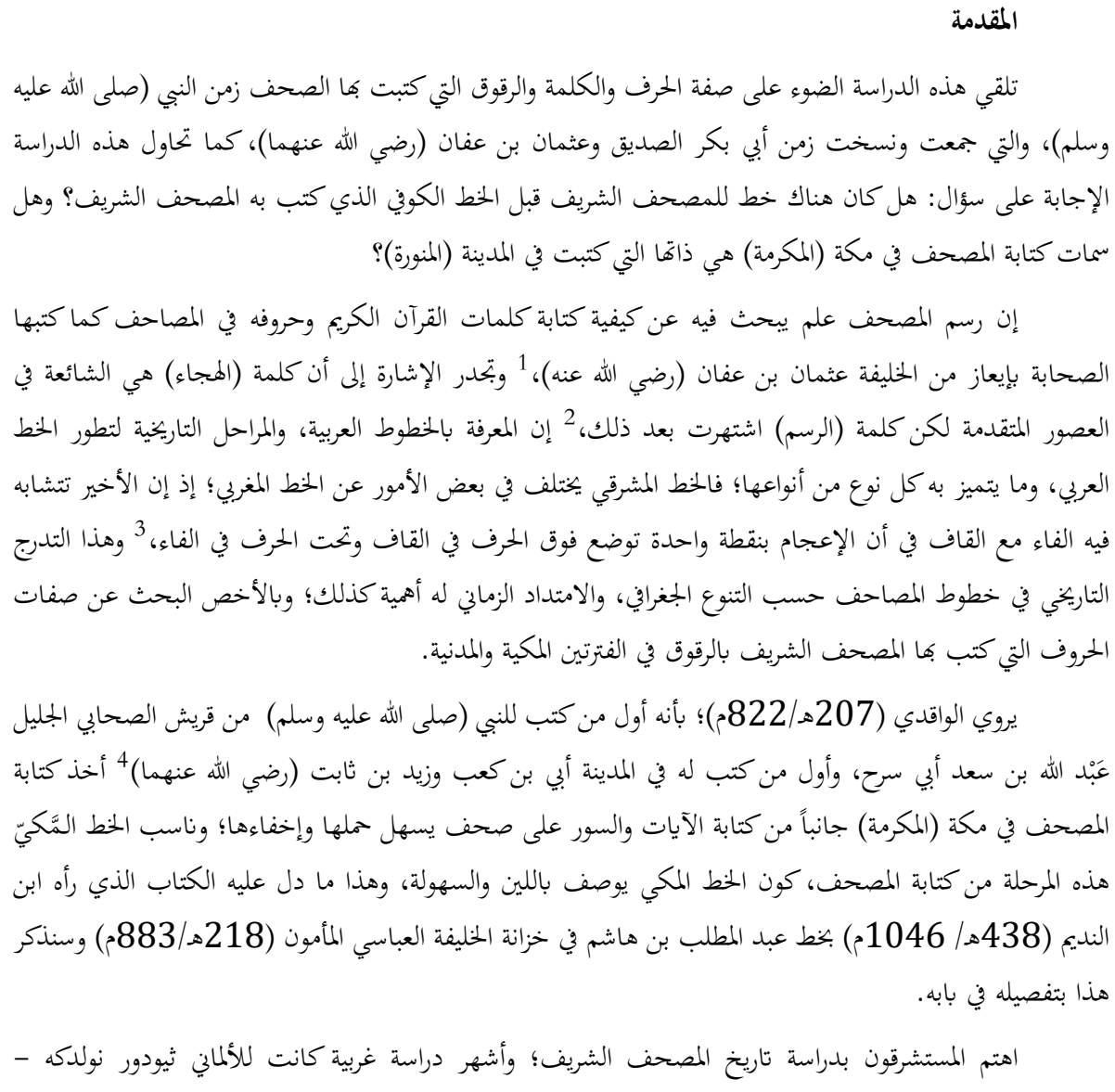


Theodor Nöldeke

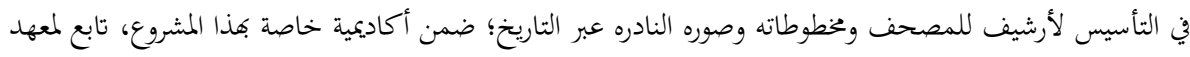

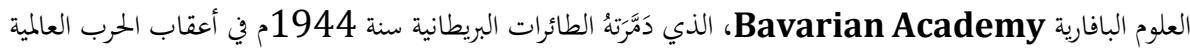

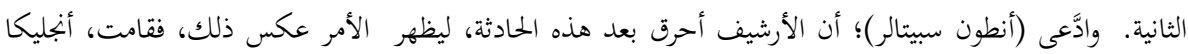
نيوفرث Angelika Neuwirth وميشيل ماركس Michael Marx؛ بكشف الأرشيف من جديد، والبدء

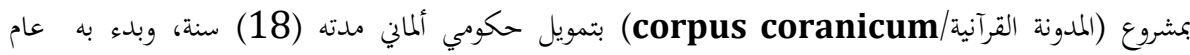

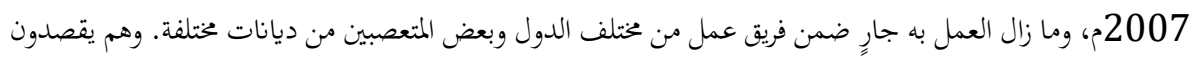

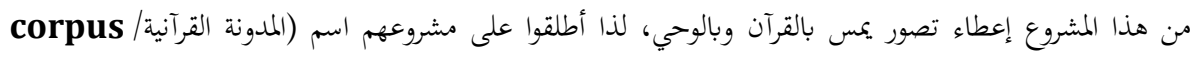
Coranicum

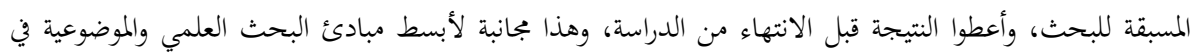

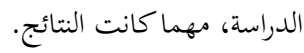

أن أدق الطرق في دراسة تاريخ المصحف الشريف وكيفية كتابته عبر التاريخ وبالأخص في القرن المجري الأول،

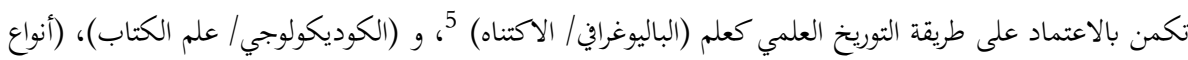

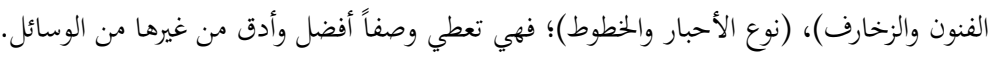

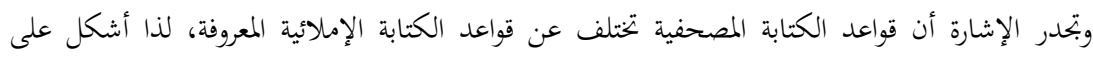

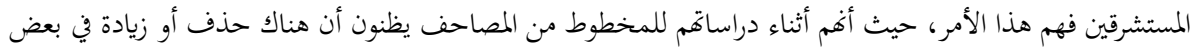

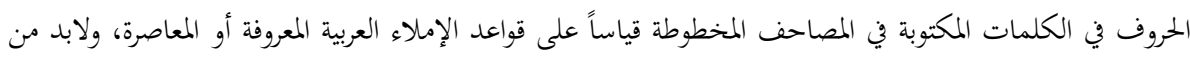

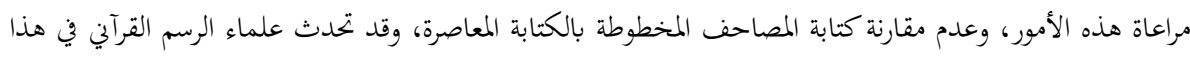

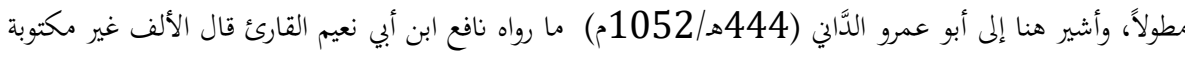

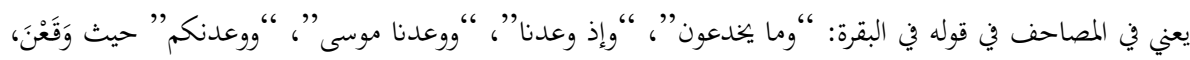

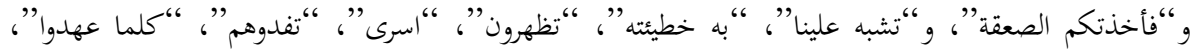

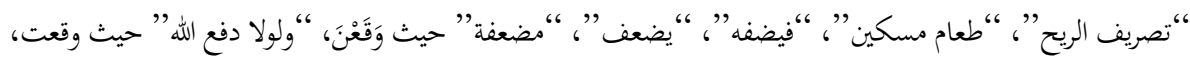

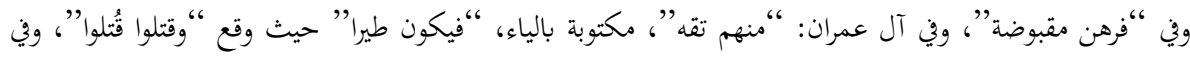

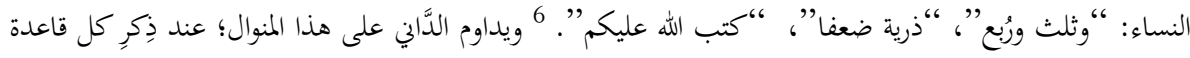

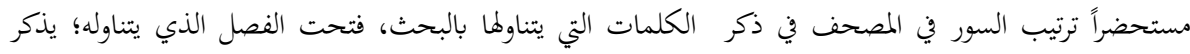
الكلمات المعنية في كل سورة على حدة، إبتداءً من سورة الفاتحة حتى سورة الناس وفق الترتيب المصحفي كما أسلفنا، ويستمر أبو عمرو الداني في كتابه بتقعيد علم الرسم، مُراعيا ما وقع فيه حذف أو زيادة أو قلب للحرف، ذاكراً 


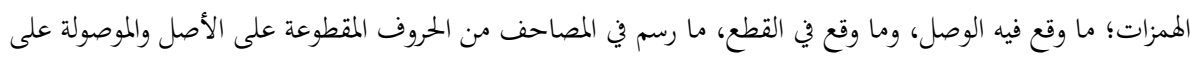

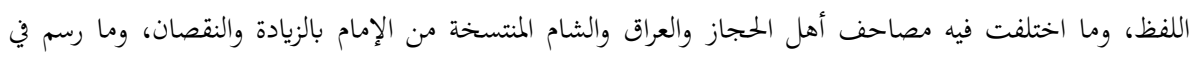

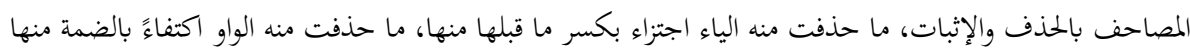

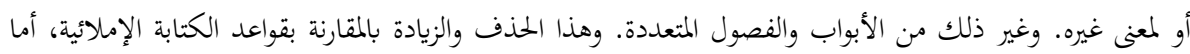

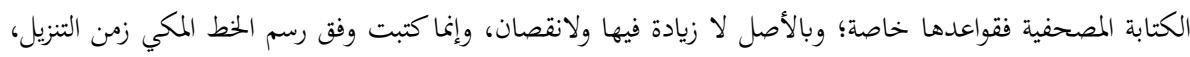

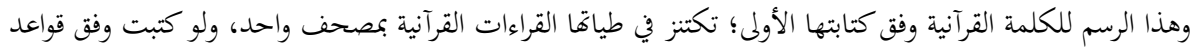

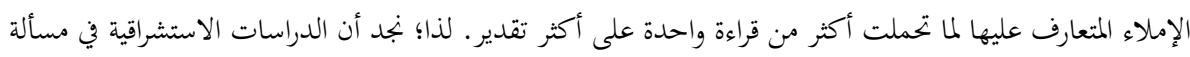

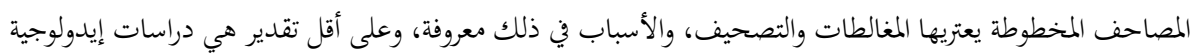

أكثر مما هي دراسات معرفية موضوعية.

\section{1. الكتابة في عهد النبي صلى الله عليه وسلم}

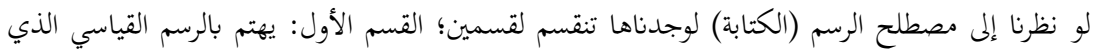

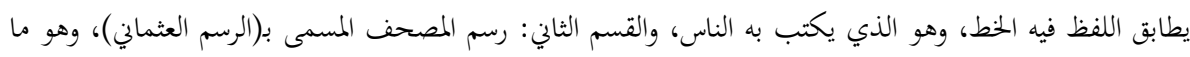

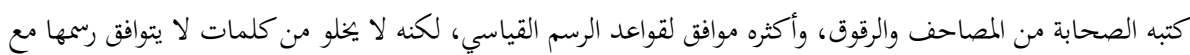

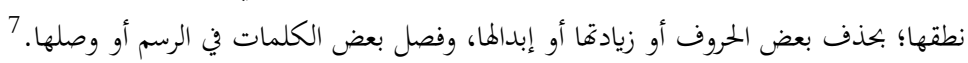

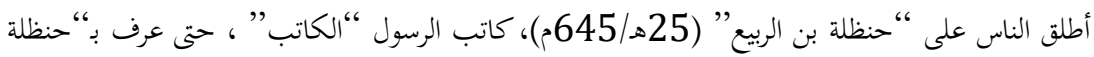

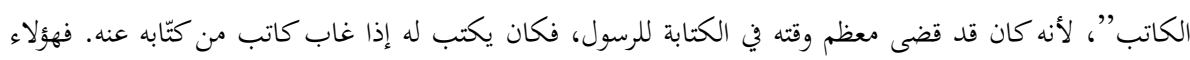

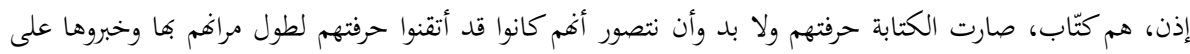

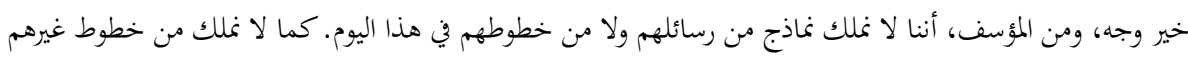

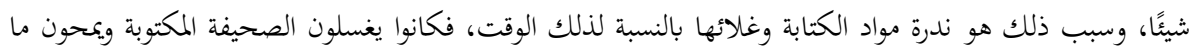

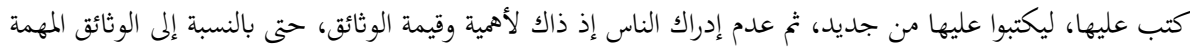

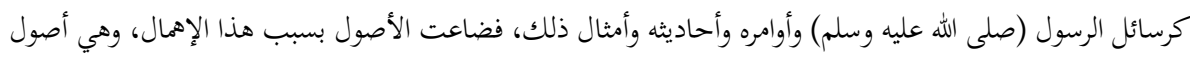

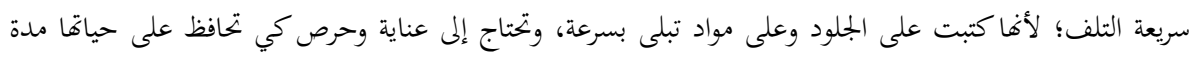

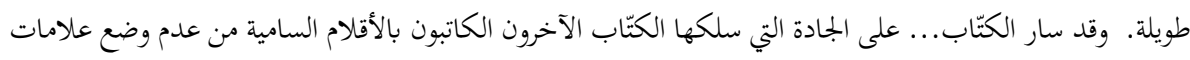

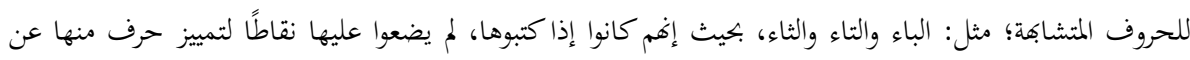

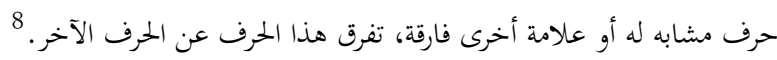

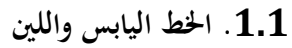

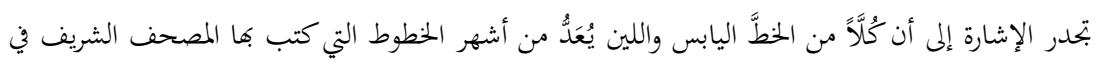

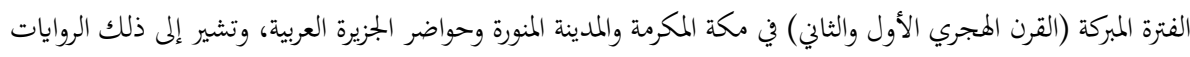

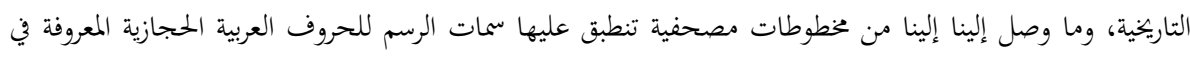

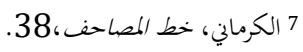




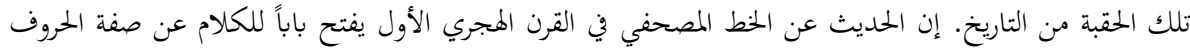

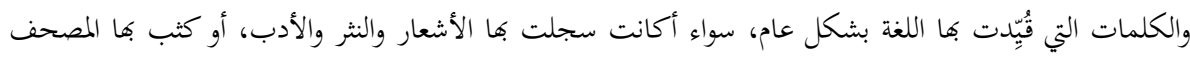

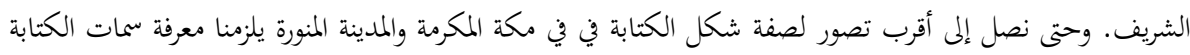

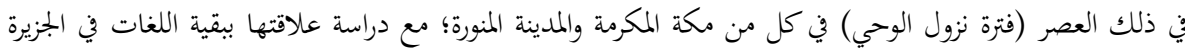
العربية وما حولها، وخصوصاً العربية الشمالية (النبطية) والعربية الجنوبية (المسندية).

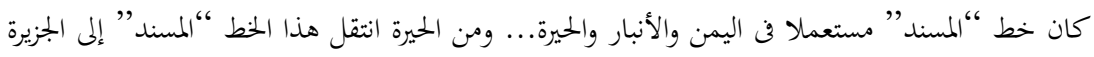

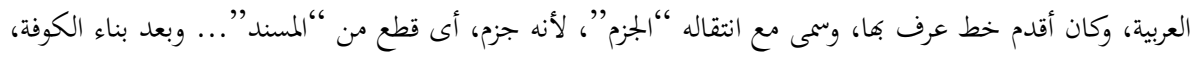

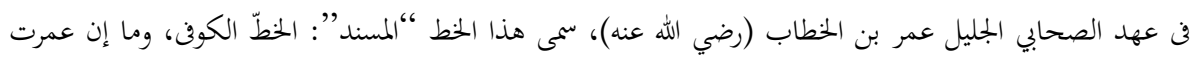

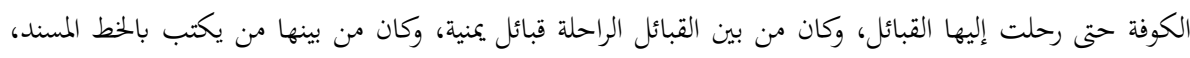

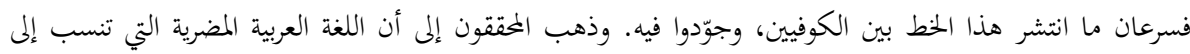

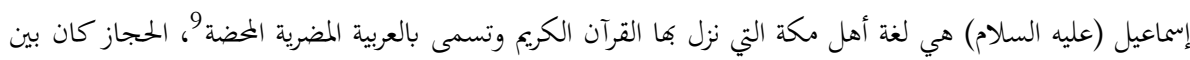

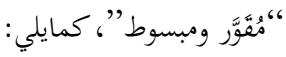

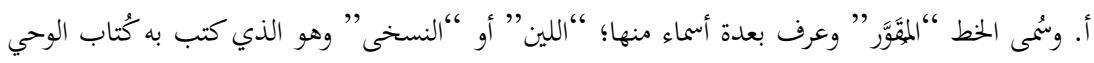

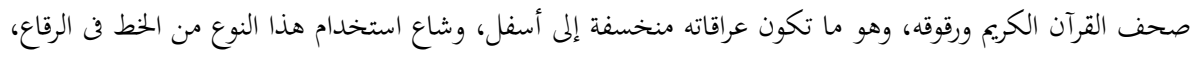

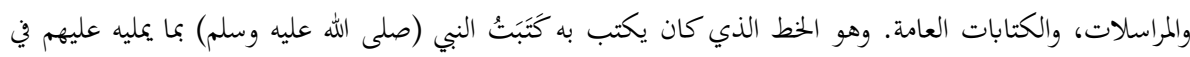
رسائله للملوك والحكام والأكاسرة والولاة. 10

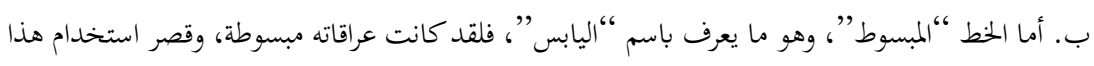

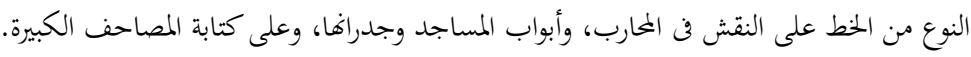

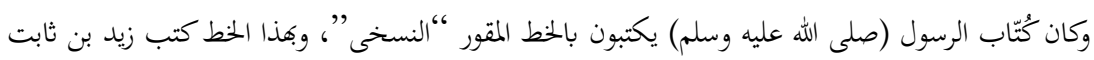

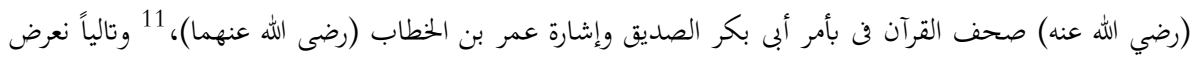

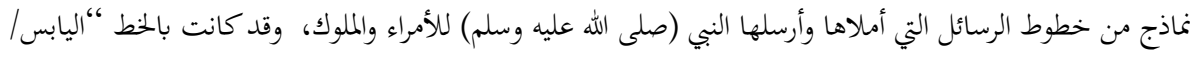

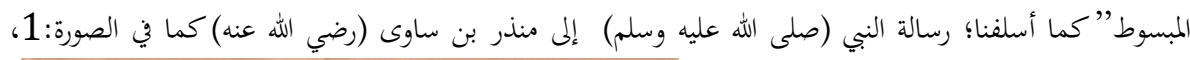
التالية:

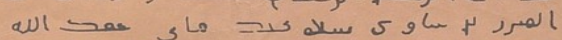

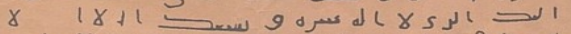

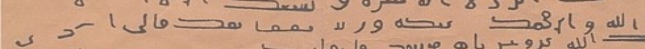

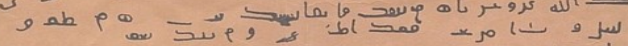

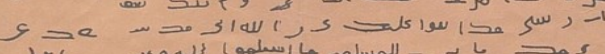

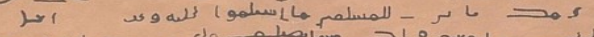

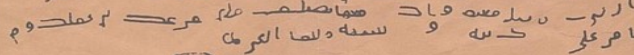
- 


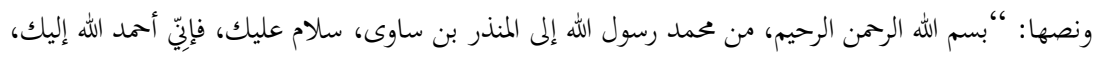

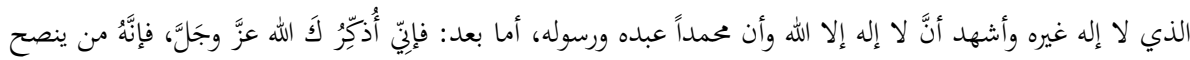

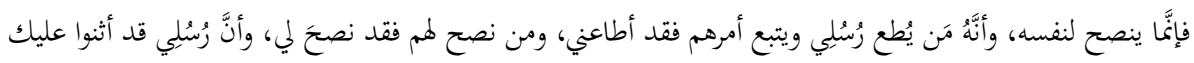

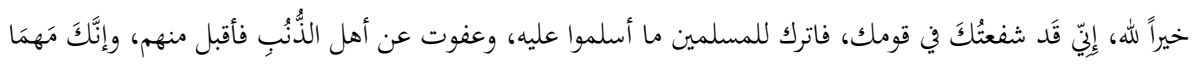

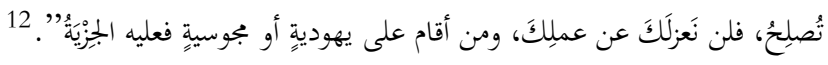

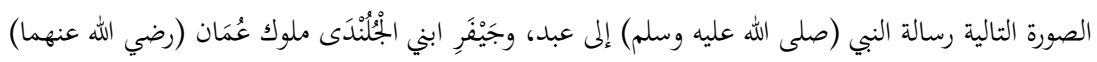

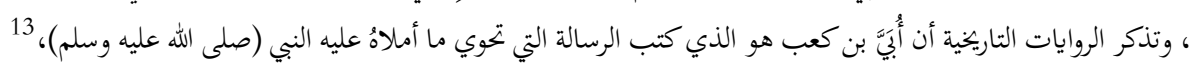

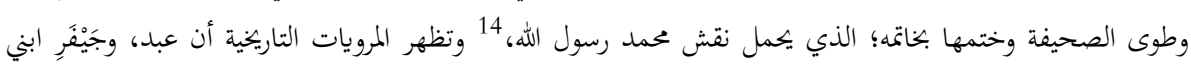

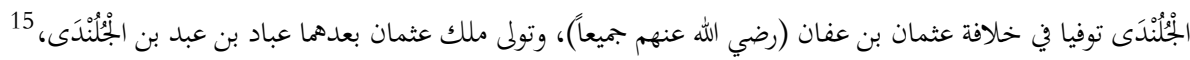
وتالياً نص الرسالة الشريفة كما في الصورة:2: الصورة:2. (2)

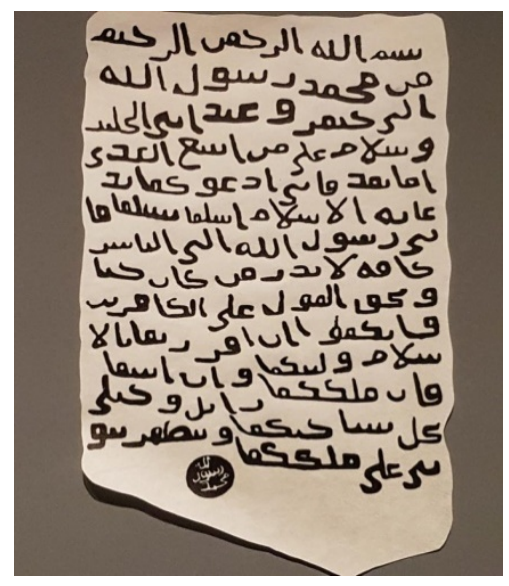

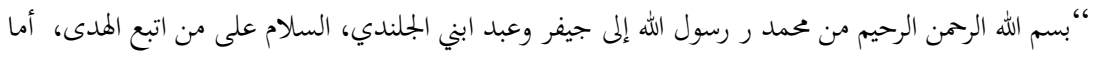

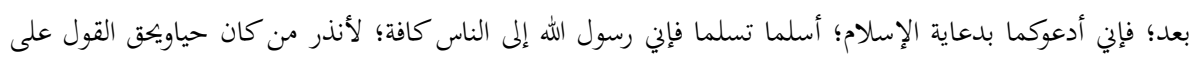

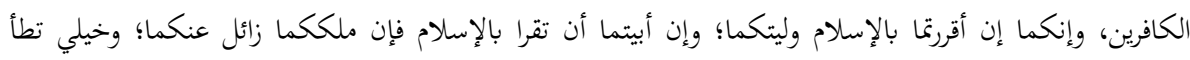
ساحتكما، وتظهر نبوتي على ملككما". هذه الرسالة وغيرها من الرسائل الشريفة التي تحمل في طياتا خطابات النبي (صلى الله عليه وسلم) للملوك

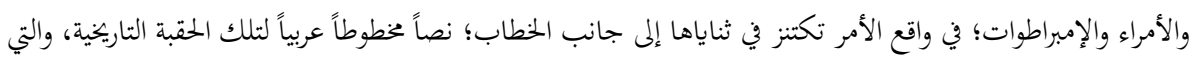

12 محمد بن جرير بن يزيد الطبري. تاريخ الرسل والملوك، (بيروت: دار التراث، ط2، 1387هـ)، 3: 29.

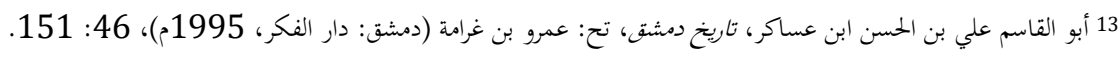

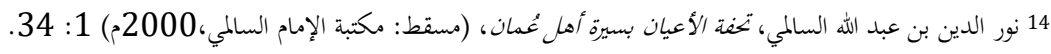

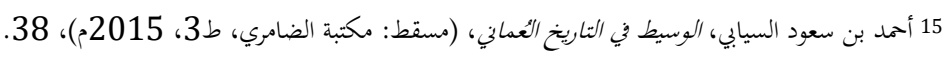


نحن في صدد البحث في ميزات حروفها وتراكيبها وجمالياتا، فالكتابة واضحة معجمة تخلو من النقط والحركات، ويظهر

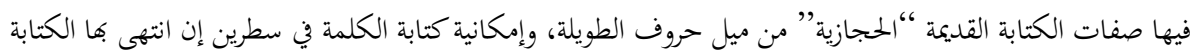

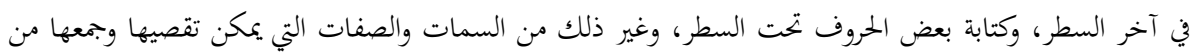
عدة مصادر مهمة، أهها: المصاحف المبكرة “العثمانية”، وغيرها من الرقوق والطروس، ورسيائل النبي (صلى الله عليه

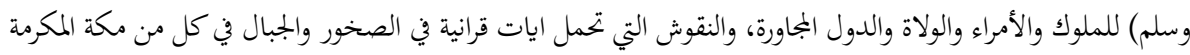
والمدينة المنورة، تحديداً، والآيات التي كتبت في المساجد والقصور والمباني في عهد بني أمية داخل وخارج الجزيرة العربية. تجدر الإشارة أن كثير من هذه الرسائل أعيد كتابتها عبر التاريخ، مع الحفاظ على مطابقة المنسوخة للأصل،

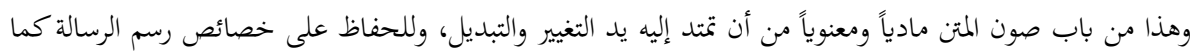
هي في الأصل. كما أسلفنا؛ فإن رقوق المصاحف التي كتبت في القرن الهجري الأول كتبت بالخط “"اللين/ المقوّر”، وبدأ

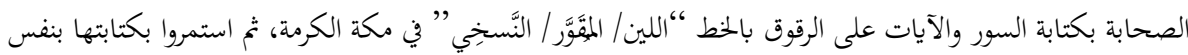

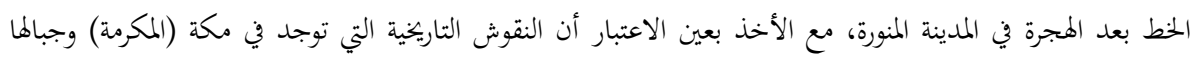

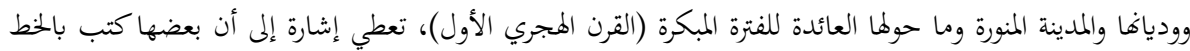

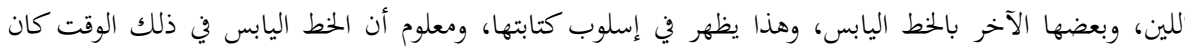

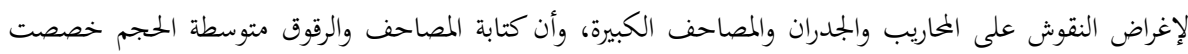
بالخط اللين؛ كما يظهر في صورة المصحف الذي عثر عليه في مكتبة بيرمنقهام؛ انظر الصورة:3؛ التالية :

الصورة: 3.

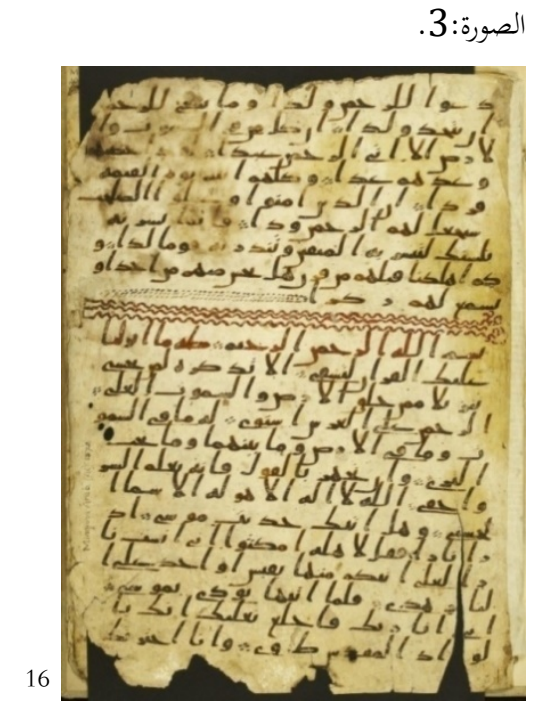

وحين جمع القرآن بالمدينة، وأرسلت المصاحف إلى مكة، والشام، والبصرة، والكوفة، وغيرها، أقبل الناس على 
الكتابة الحجازية للمصحف الشريف في صدر الإسلام

نسخ القرآن الكريم، وأصبحت لكل إقليم طريقة تميز بما عن غيره، وكان لها اسهها، ونشأ عن ذلك:

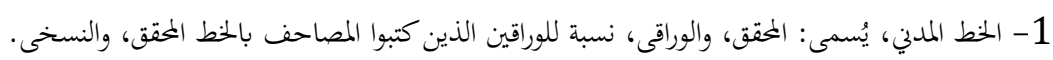

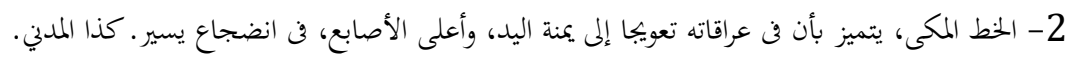
3- الخط البصرى “"الكوفى، الأصفهان، العراقى" ، وكان على ثلاثة أنواع: المدور، والمثلث، والثئم (وهو خط

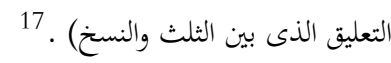

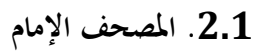

المصحف الإمام؛ هو المصحف الرمي الذي تم جمعه وكتابته في زمن أبي بكر الصديق (رضي الله عنه)، ثم

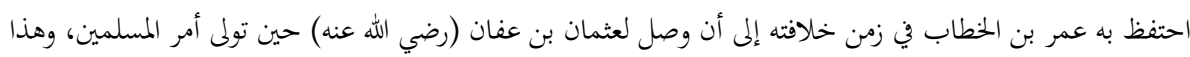

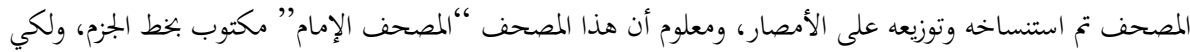

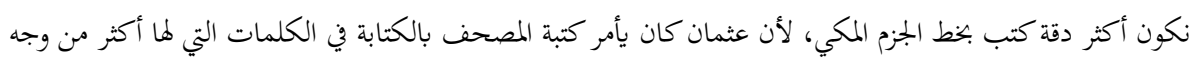

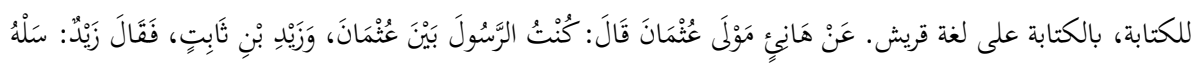

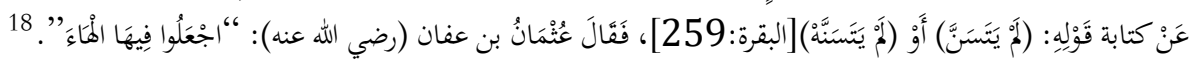
وقد كتبت بالتاء المربوطة على قاعدة الرسم المكي، وإن تضمنت الكلمة كلمة كلا القرائتين؛ اللفظ بالهاء و الألف المقصورة.

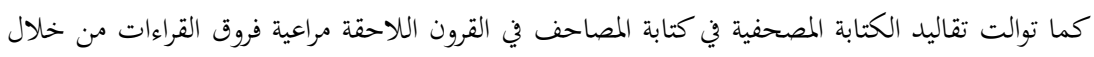

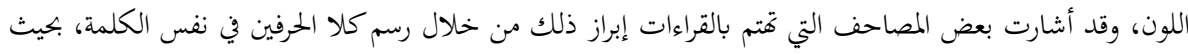

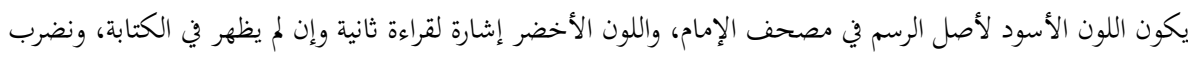

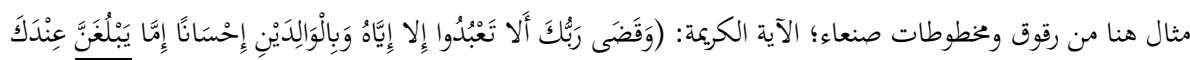

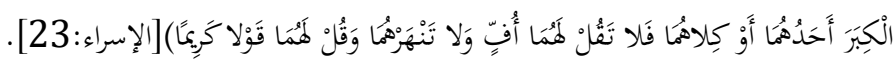

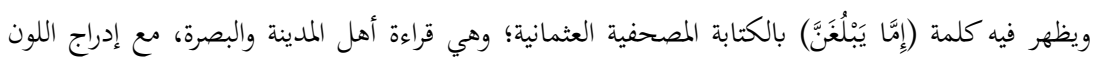

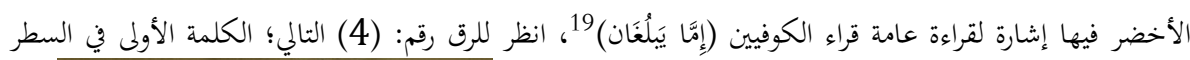

(17,20)

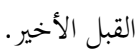

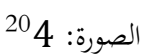

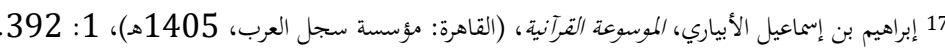

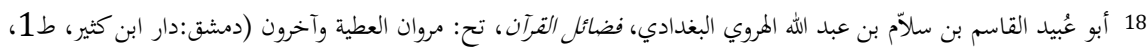

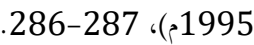

19 عممد بن جرير الطبري، جامع البيان عن تفسير آي القرآن، تح: أممد عمد شاكر (بيروت: مؤسسة الرسالة 11، 1420هـ)،

20 Șan'a, Unesco "Memory of the word" Program Șan'a Manuscripts, (Qur'anic Manuscripts) 73. 
لم يجزم الباحثون في هذا الخصوص بقطعية العثور على المصحف الإمام، وإن كثرت الدعاوى على ذلك.

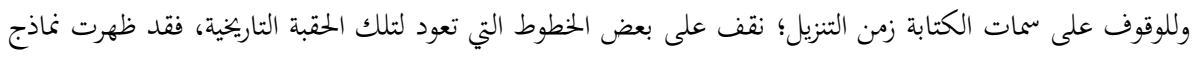

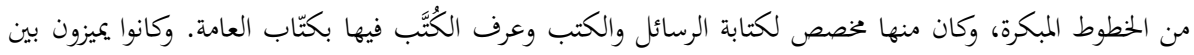

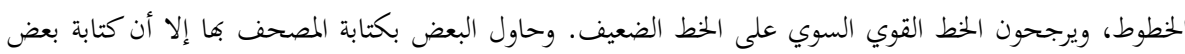

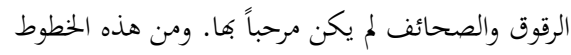

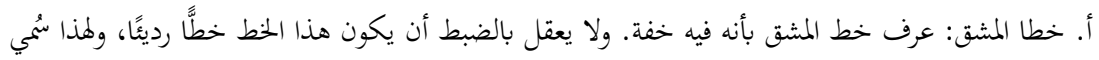

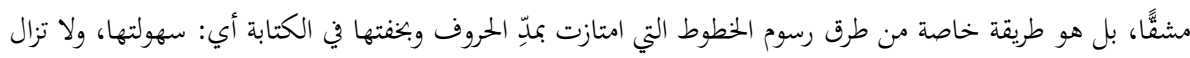

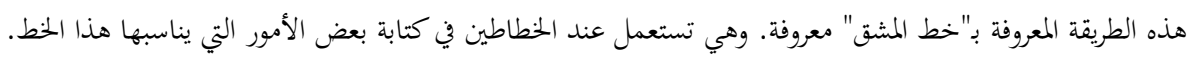

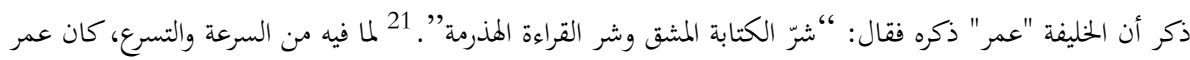

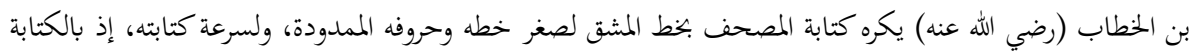

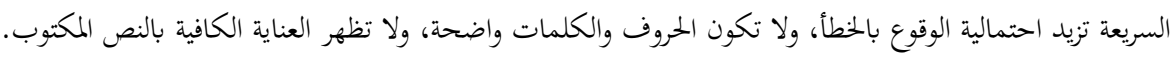

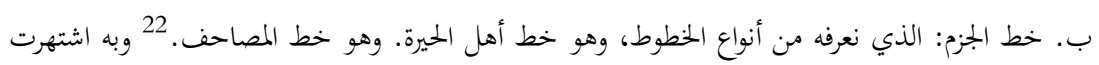

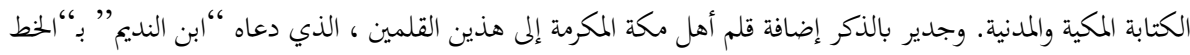

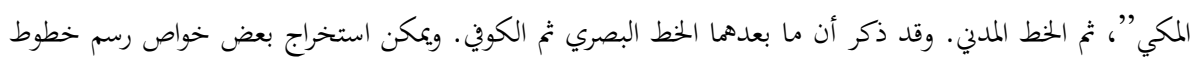

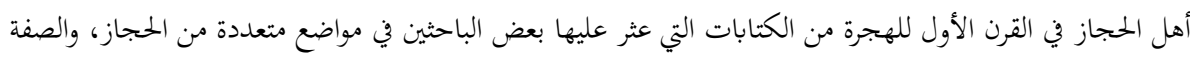

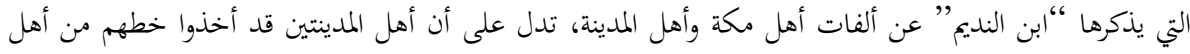

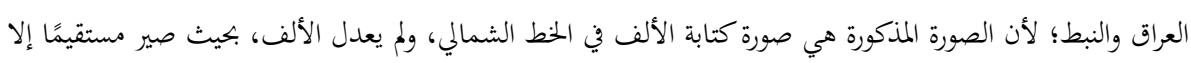
في الإسلام. 23

\subsection{1 بداية نقط المصاحف وتشكيلها}

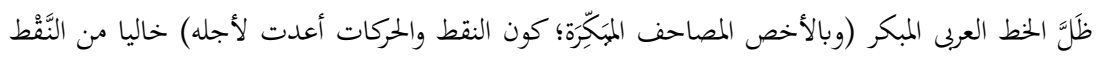

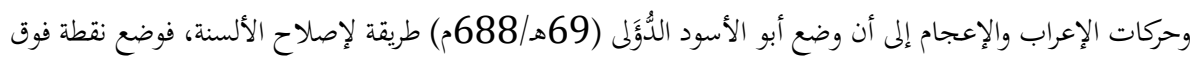

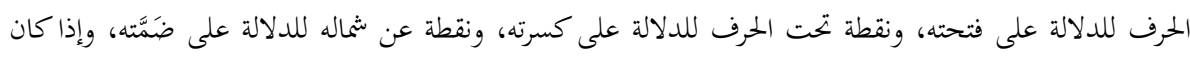

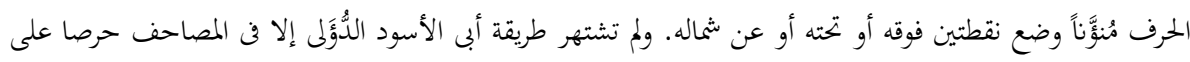

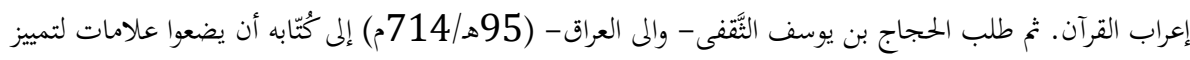

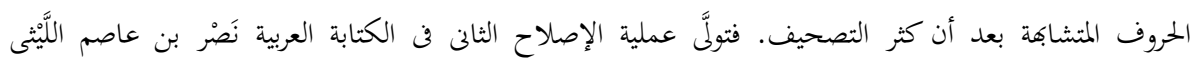

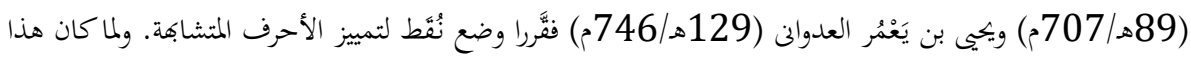

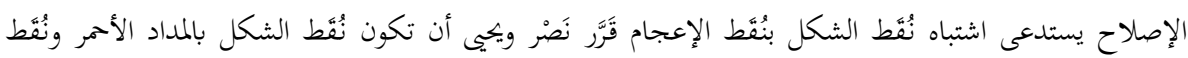


الإعْجام بنفس مداد الحروف. وأخيراً وضع عالمُ اللغة الشهير الخليل بن أحمد الفراهيدى (170هـ/879م) طريقة جعل

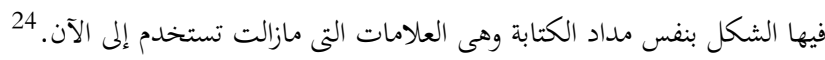

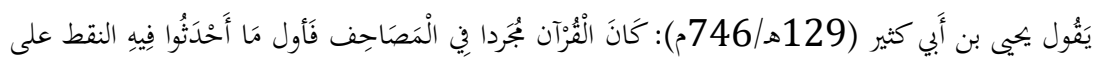

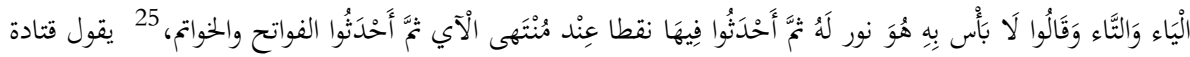

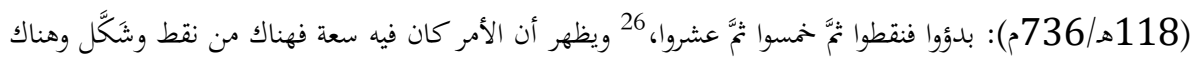

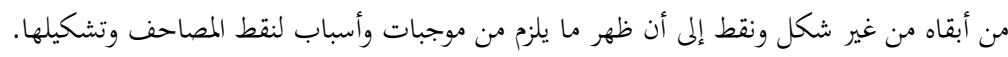

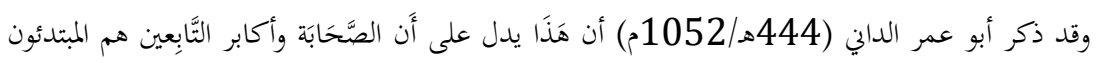

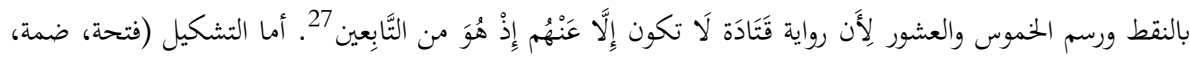

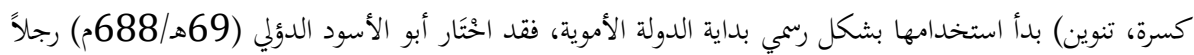

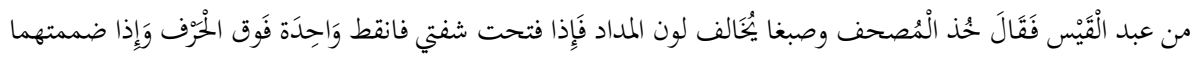

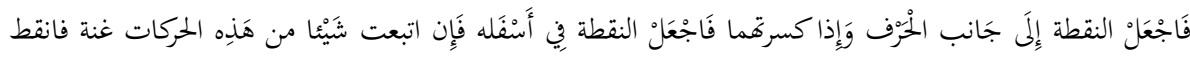

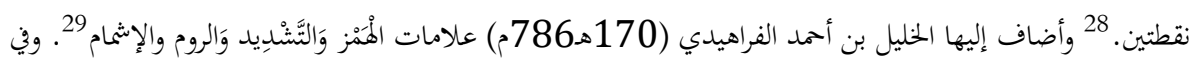

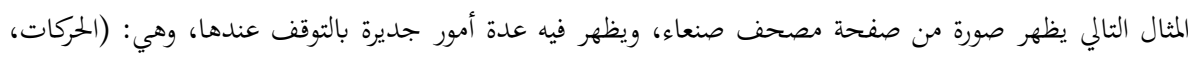

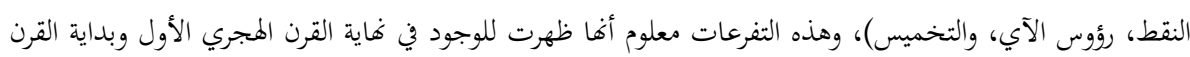

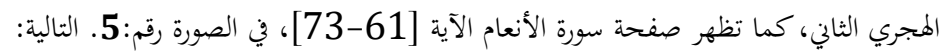

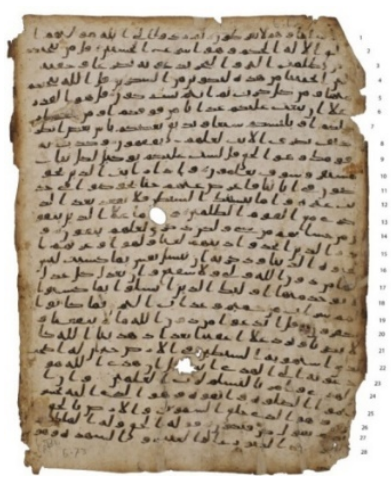

24 عمود حمدي زقزوق، وآخرون، موسوعة المفاهيم الإسلامية العامة، (القاهرة: الجلس الأعلى للشئون الإسلامية، 2000م)، 1:

25 عثمان بن سعيد بن عثمان بن عمر أبو عمرو الداني، المحكم في نقط المصاحف، تح: عزت حسن (دمشق: دار الفكر، ط233، 2 1407 1407

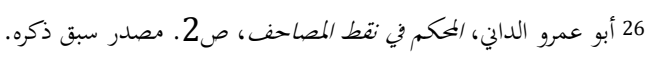

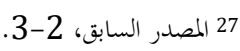
28 المصدر السابق، 4.

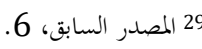

30 San`a, "Dār al-mahtūțāt", Haus der Handschriften, YE, DAM 01-27. (Erișim 11 Ocak 2020). 
وهذه الصحيفة من رقوق مصاحف صنعاء، كتبت بالحط اللين المِّكّي؛ وبه كتبت المصاحف والرقوق الأوَّل،

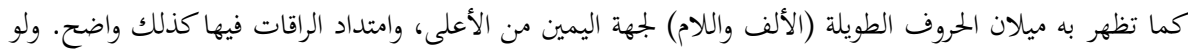

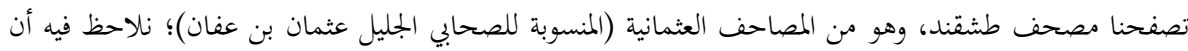

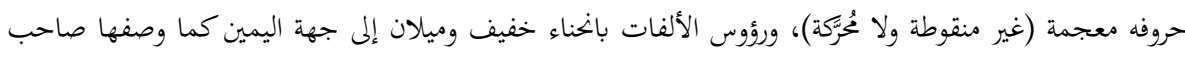

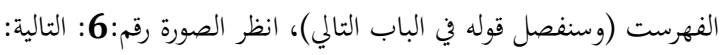

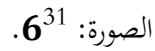

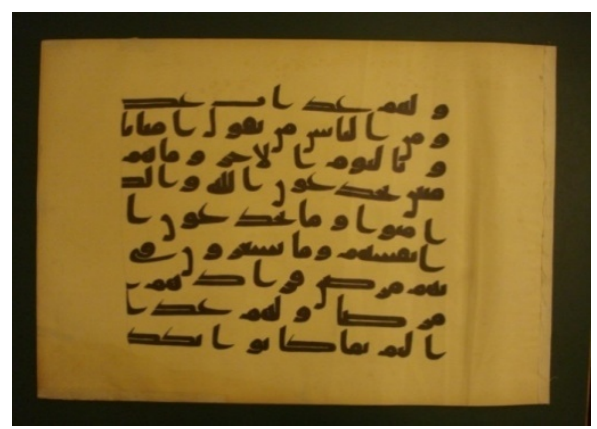

وقد سار على الجادة التي سار عليها غيرهم من عدم وضع علامات خاصة بالحركات. فكتبوا ما كتبوا من غير

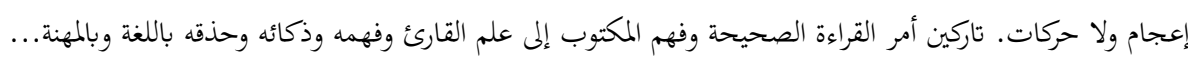

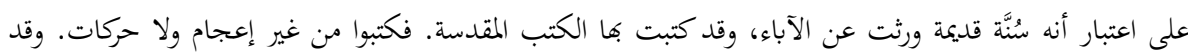

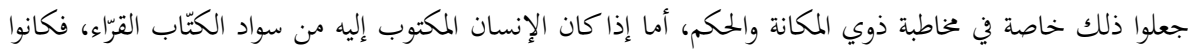
يبيحون لأنفسهم حرية إعجام الكتابة وتحريكها.

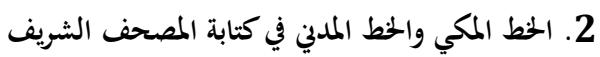

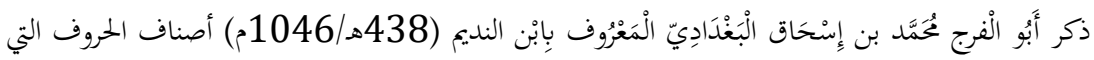

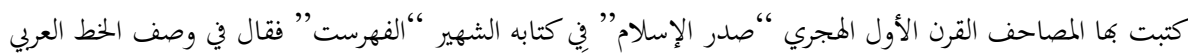

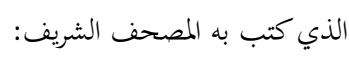
فأول الخطوط العربية الخط المكي وبعده المدني ثم البصري ثم الكوفي فأما المكي والمدني ففي ألفاته تعويج إلى

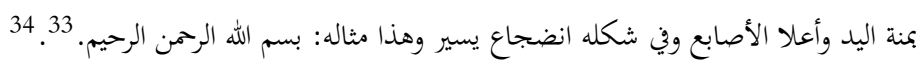

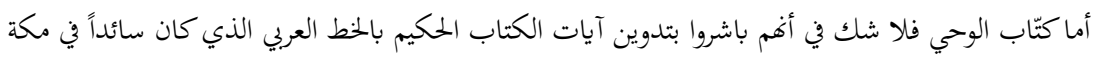

31 Berlin, "Staatsbibliothek", Kodex Samarkand, Sankt Petersburg 1905, DE -002. (Erişim 5 Ocak 2020).

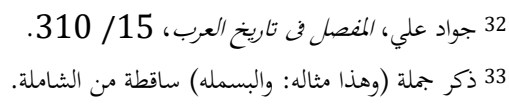

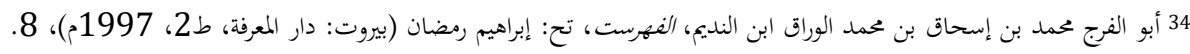

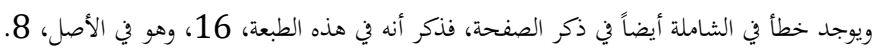




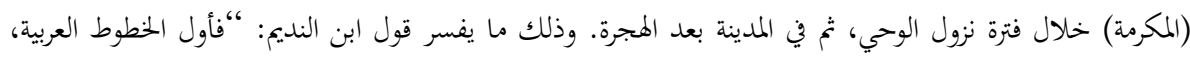

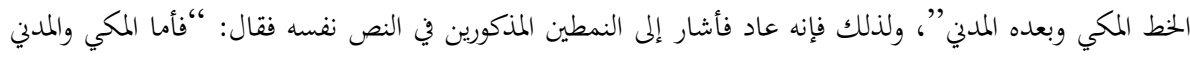

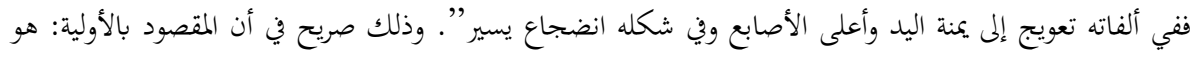

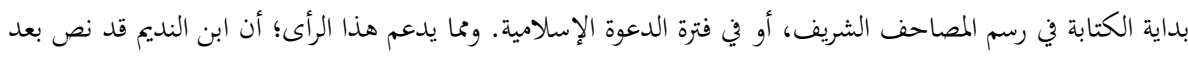

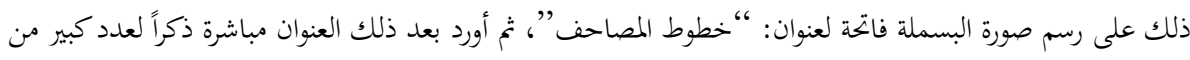

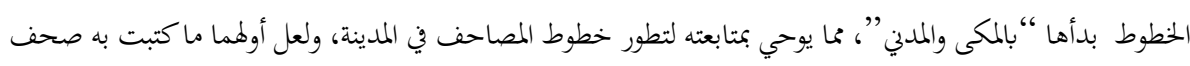

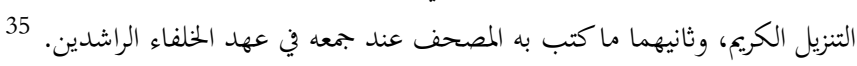

1.2. تحليل النص الذي ذكره ابن النديم (438هـ/1046م) مع المثال الذي أورده ابن النديم في

\section{حديثه عن خطوط المصاحف المبكرة}

تحليل النص الذي يتحدث عن أنواع الخط العربي الذي كتب به المصحف في صدر الإسلام. أول ما نبدأ به

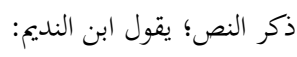

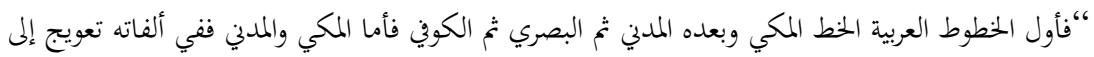

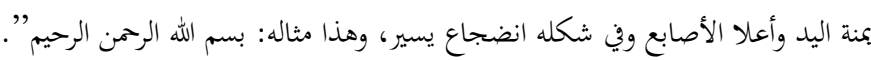

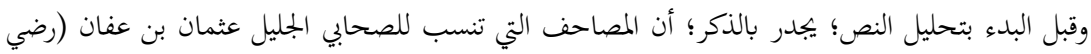

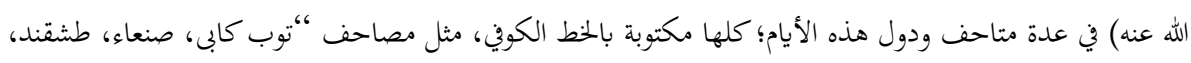

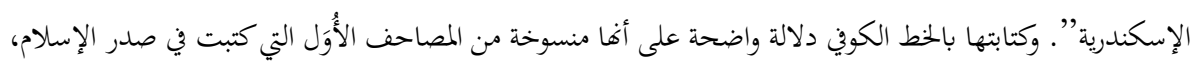

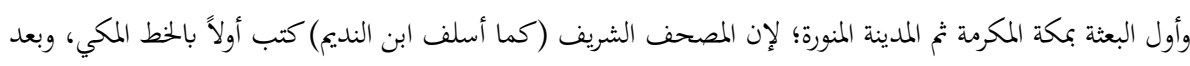

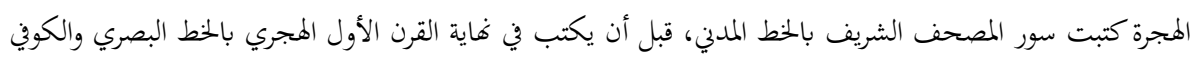

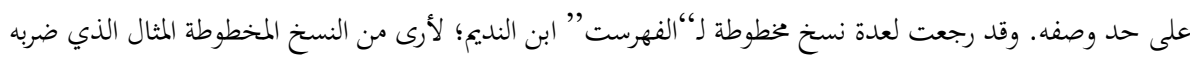

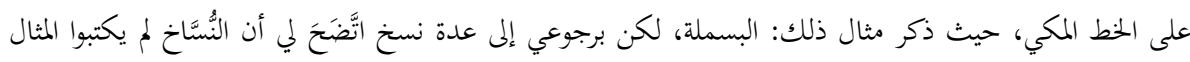

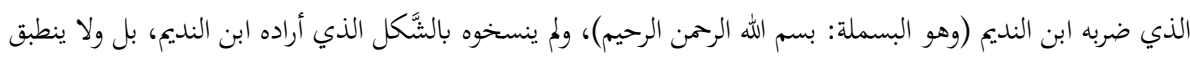

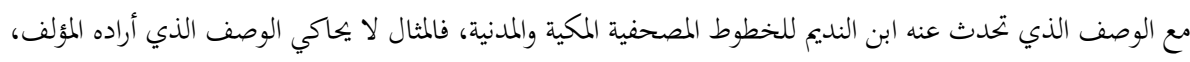

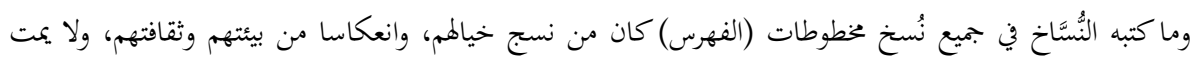

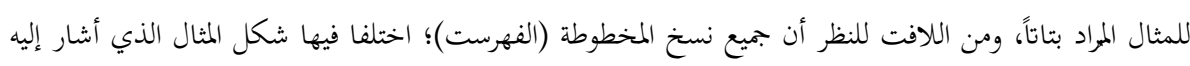

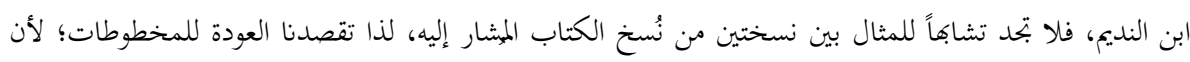

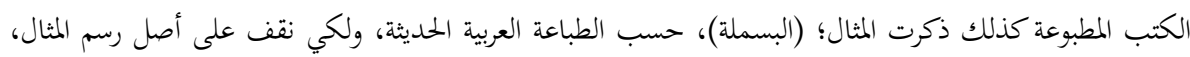

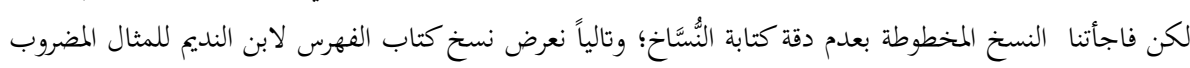

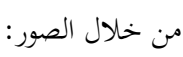

35 صالخ بن عبد الله ابن مميد، نضرة النعيم في مكارم أخلاق الرسول الكرمه، (جدة: دار الوسيلة، ط4، د.ت.)، 217/1. 


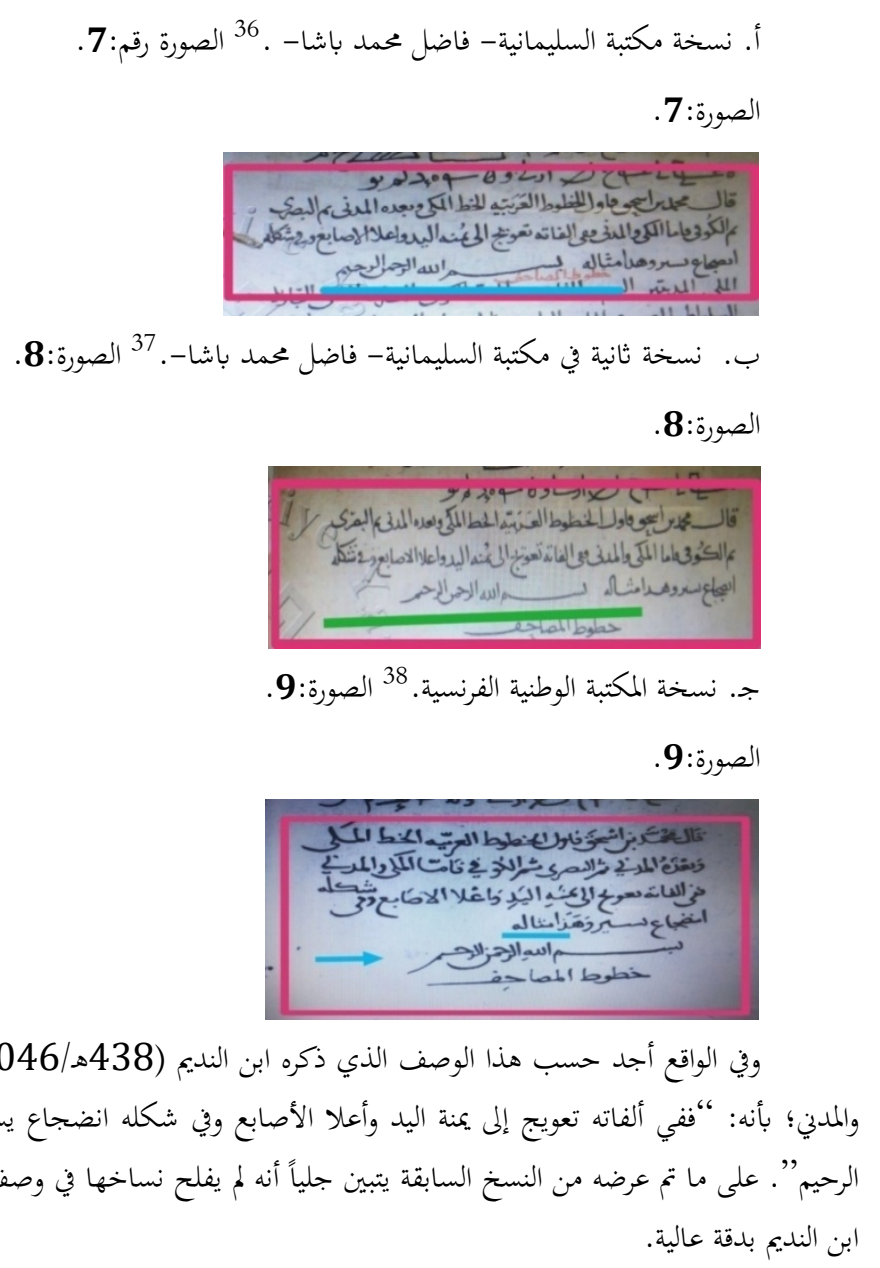

$$
\text { 2.2. تحليل كلام ابن النديم في وصف المصحف المكي والمدلي: }
$$

1.2.2. خط المصحف المكي وخط المصحف المدني؛ يقول ابن النديم في خط المصاحف المكية والمدنية:

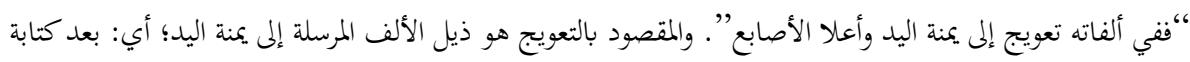

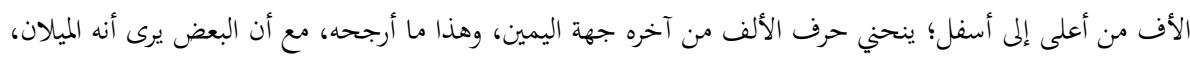

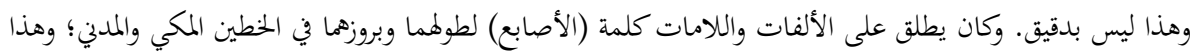

36 İbnü'n Nedîm, Ebü'l-Ferec Muhammed b. Ebî Ya'kūb İshâk b. Muhammed b. İshâk, elFihrist, (İstanbul: Süleymaniye Kütüphanesi, Fazll Ahmed Paşa, 1135), 3a.

37 İbnü'n Nedîm, Ebü'l-Ferec Muhammed b. Ebî Ya'kūb İshâk b. Muhammed b. İshâk, elFihrist, (İstanbul: Süleymaniye Kütüphanesi, Fazıl Ahmed Paşa, 1134), 3a.

38 İbnü'n Nedîm, Ebü'l-Ferec Muhammed b. Ebî Ya'kūb İshâk b. Muhammed b. İshâk, elFihrist, (Fransa: Milli Kütüphanesi, btv, 1b110038486), 6b. 
مثاله في الصورة رقم :10.

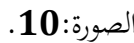

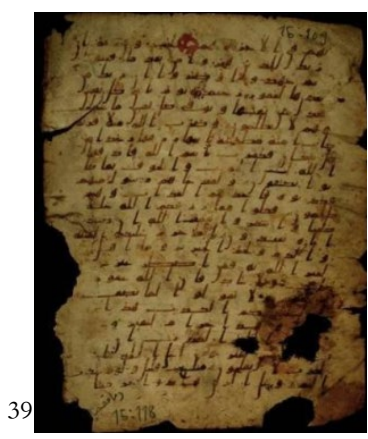

2.2.2. ما يتميز وتشترك به خطوط المصاحف المكية والمدنية.

يقول ابن النديم (438هـ/1046م) في خط المصاحف المكية والمدنية: فني ألفاته تعويج إلى يمنة اليد وأعلا

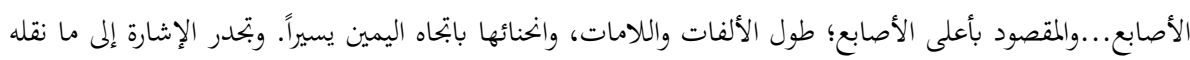

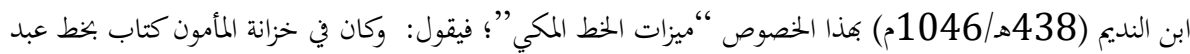

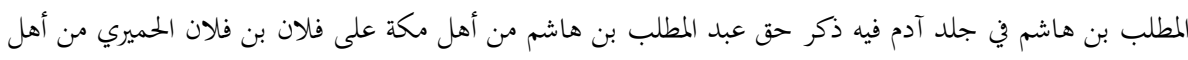

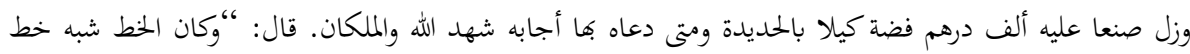

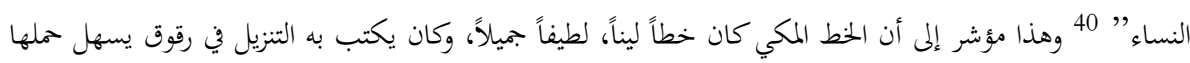
وإخفاءها.

\section{3. كتابة المصاحف في فترة الدولة الأموية.}

قال ابن اسحق: أول من كتب المصاحف في الصدر الأول ويوصف بحسن الخط خالد الد بلد بن أبي الهياج

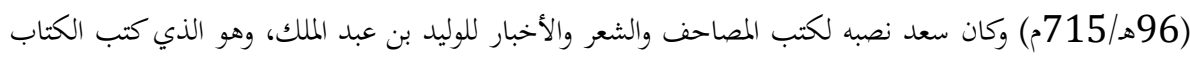

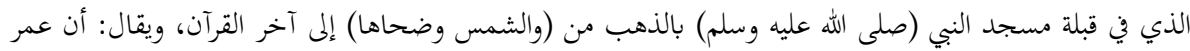

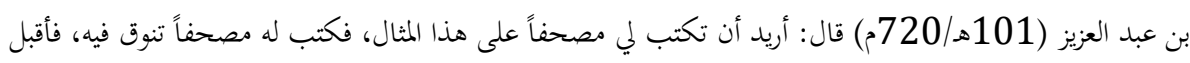

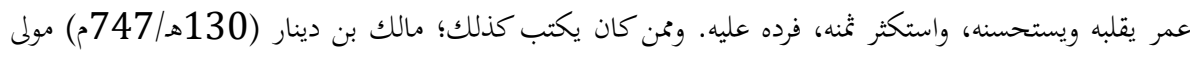

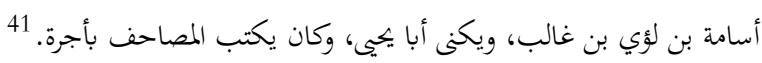

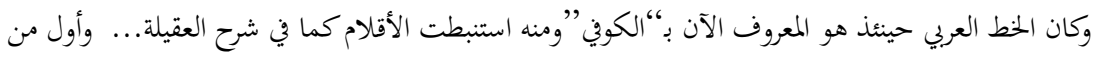

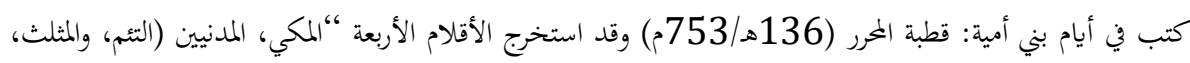

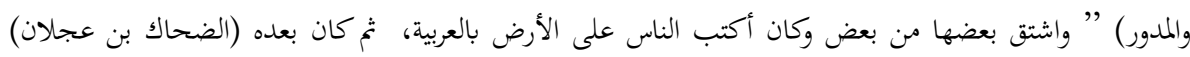

39 Șan'a, Unesco "Memory of the word" Program Șan'a Manuscripts, (Qur'anic Manuscripts) 28.

$$
40 \text { ابن النديه، الفهرست، 16. } 16 \text { ابن النديم، الفهرست، 9-10. }
$$


الكاتب في أول خلافة بني العباس فزاد على قطبة، فكان بعده أكتب الحلق، ثم كان إسحاق بن حماد الكاتب في خلافة الكانة

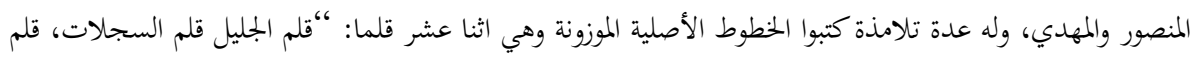

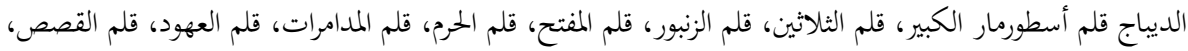
قلم الحرفاج”.

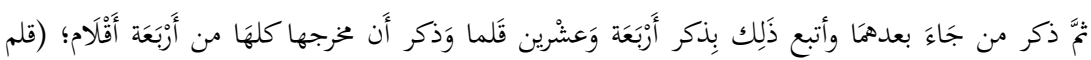

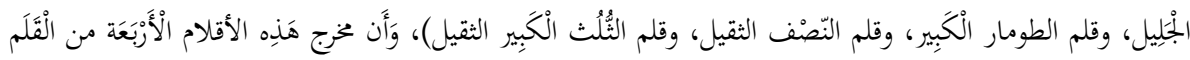

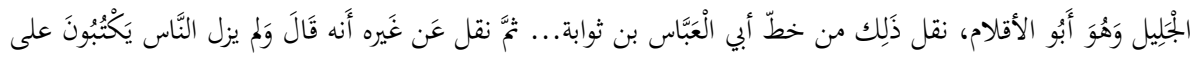

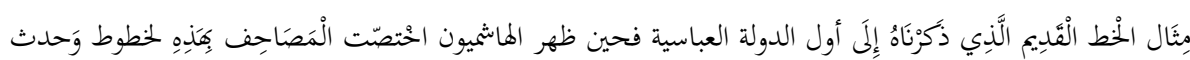

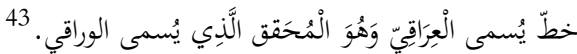

لقد تباينت الروايات في الأصل الذي اشتق منه الخط العربي؛ فأكثرها ذكرت أنه مشتق من المسند... ولم يعثر

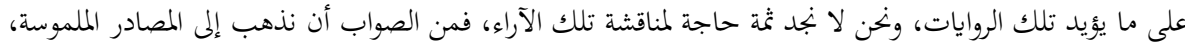

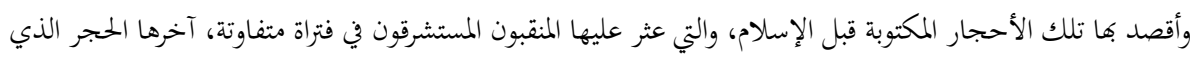

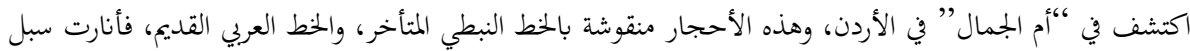

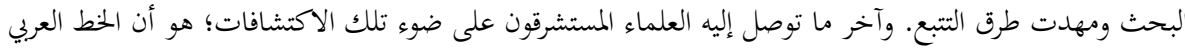

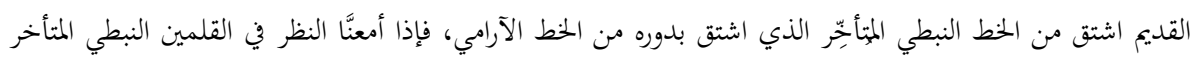

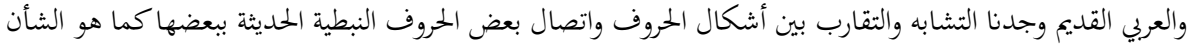

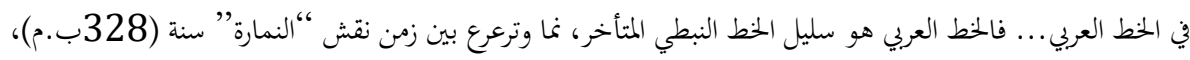

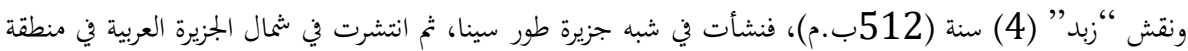

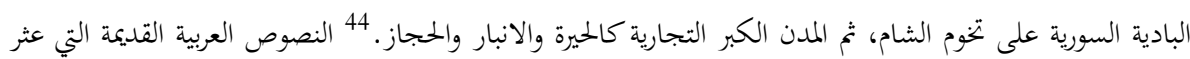

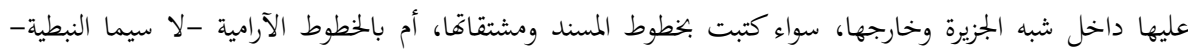

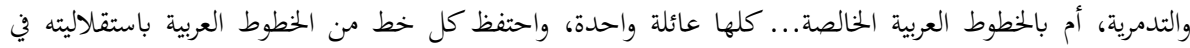
خصائص الحرف ورسمه في داخل الكلمة، وهذا ما يظهر جلياً في رقوق المصاحف المكية والمدنية والأموية.

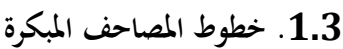

يسرد ابن النديم أن أنواع الخطوط المصحفية، ويذكر منها: المكي، المدنيين، التئم، والمثلث، والمدور، الكوفي، المئي

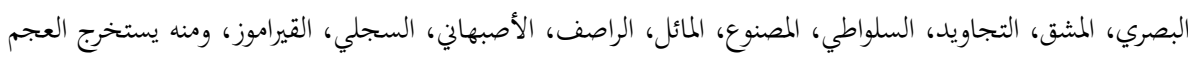

42 أبو الطيب محمد صديق خان الحسيني البخاري القِنَّجي، أبيد العلوم، (عمان: دار اين حزم، 11، 2002م)، 1: 388.

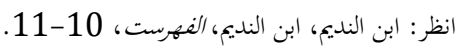
43 طاهر بن صالخ بن أممد الجزائري السمعوين، توجيه النظر إلى أصول الأثر، تح: عبد الفتاح أبو غدة (حلب: المطبوعات الإسلامية،

44 ناصر النقشبندي، “" 19نشأ الخط العربي وتطوره لغاية عهد الخلفاء الراشدين”، جلة سومر جلد3 (1947م)، 1: 129. 
وبه يقرون حدب قريبا وهو نوعان الناصري والمدور. 45

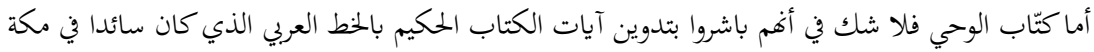

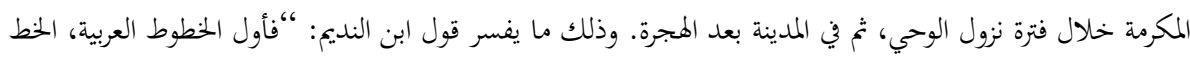

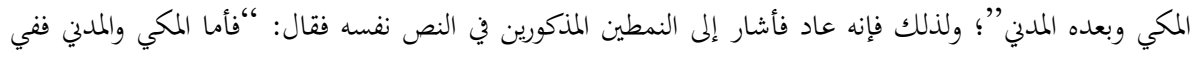

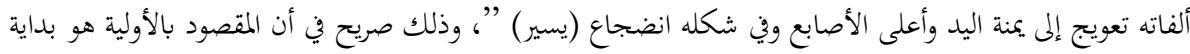

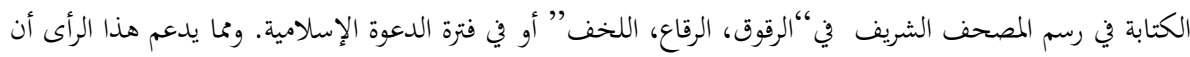

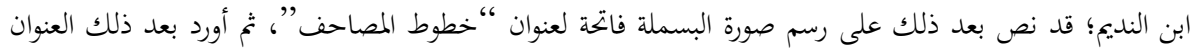

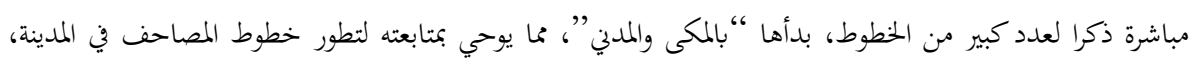

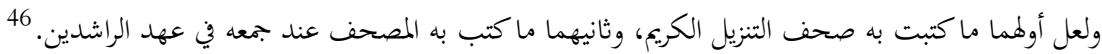

\section{3. خطوط المصحف في غهاية القرن الأول}

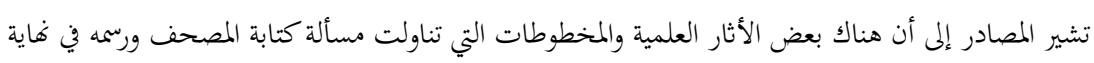

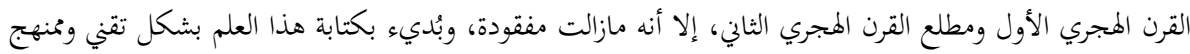

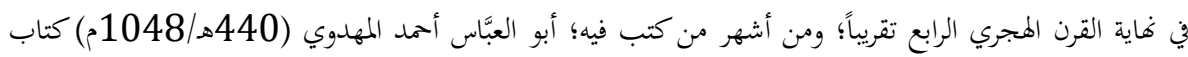

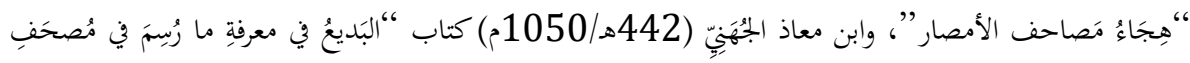

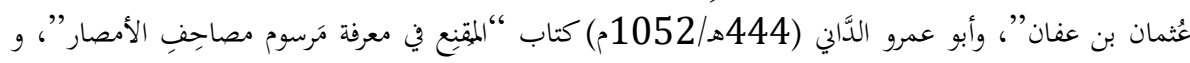

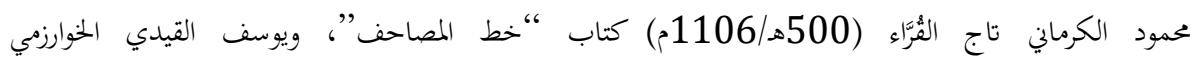

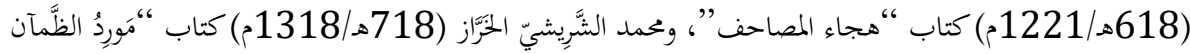

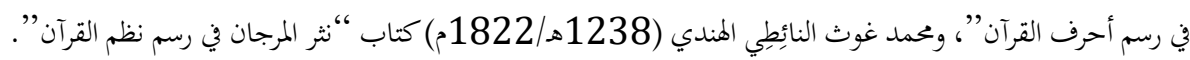

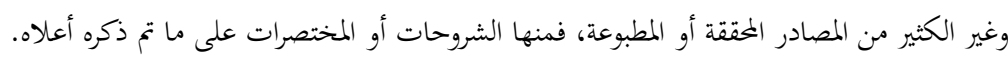

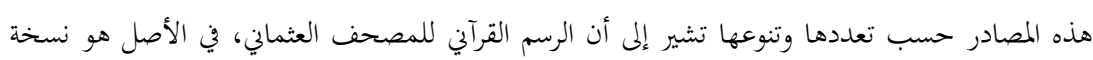

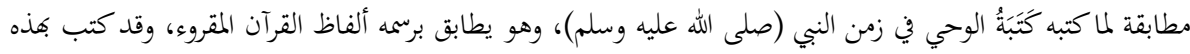

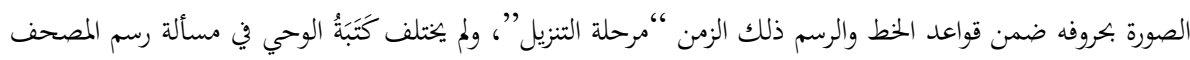

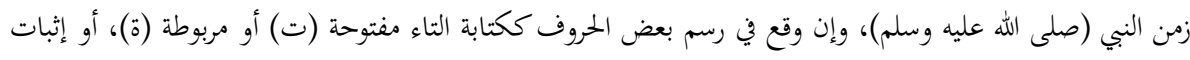

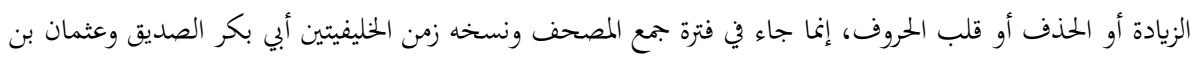

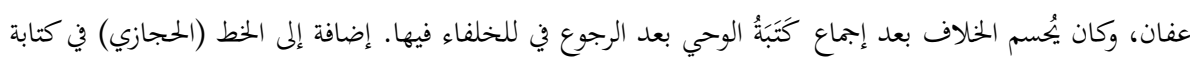

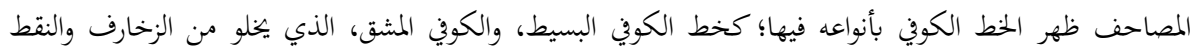

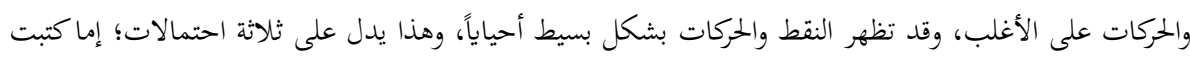

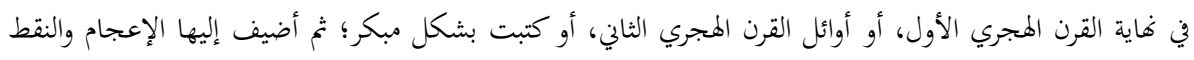

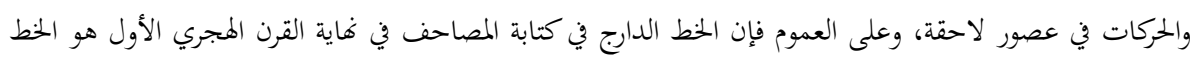

45

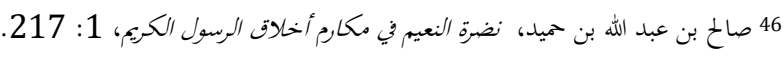


المكي والمدني ثم الكويف البسيط. انظر صورة الرق رقم:11

الصورة:11 11

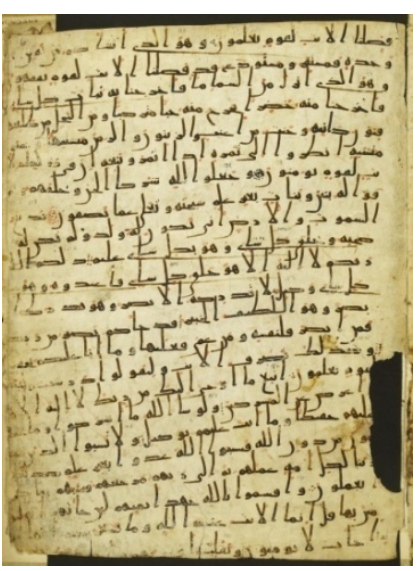

هذا الرق 48 من المصحف الشريف من أواخر القرن الهجري الأول، ويتضح ذلك من خلال حروف المشق (الممدودة بشكل أفقي فيه)، وطول حروف الألف واللام دالة على أنه من صفات الحروف المكية والمدنية، والإعجام

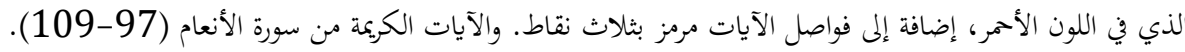

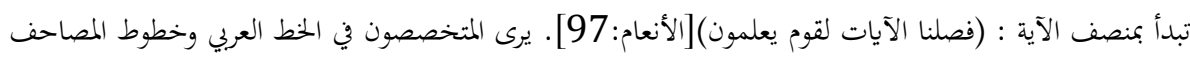

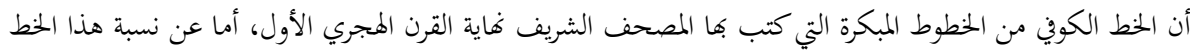

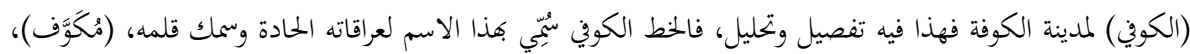

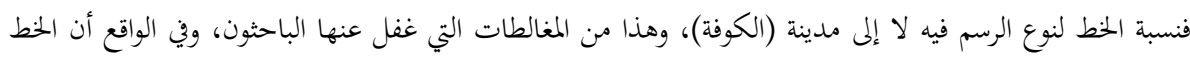

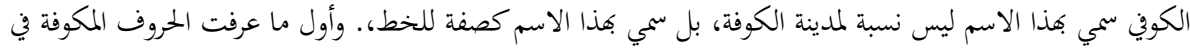
المدينة المنورة، بعد منتصف القرن الهجري الأول.

تنوع بعد القرن الهجري الأول الخط الكوفي إلى أنواع أربت على خمسين نوعاً ومن أشهرها المحرر والمشجر والمربع

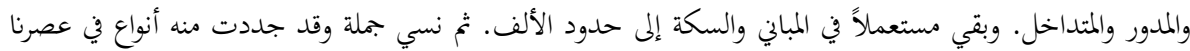
أما تاريخ خطنا المستعمل الآن فحدث في آخر الدولة الأموية أن استنبط "قطبة المحرر" من الخط الكوفي والحجازي خطاً

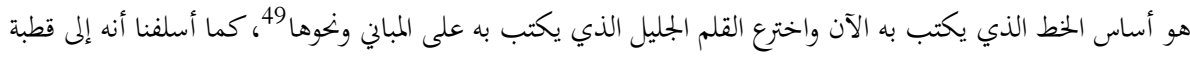
المحرر (136هـ/753هـ) يعزى اختراع القلم الجليل، الذى ينسب إليه الخط الجليلى، أى الكبير الواضح. وكان ثمة في فئي

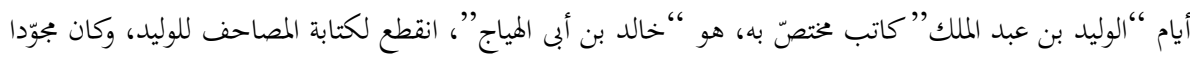

47 Adbury Research Library “University of Birmingham” Islamic Arabic, 1572 (Erișim 1 Mayis 2020).

48 Adbury Research Library "University of Birmingham", Islamic Arabic 1572, Bkz "Birmingham, GB" -004:129- 22-30 Zeilen, (Erişim 7 Mayıs 2020). 
في كتابتها. “"ابن أبى الهياج” هذا هو الذى كتب بالذهب على محراب مسجد النبى (صلى الله عليه وسلم) في المدينة

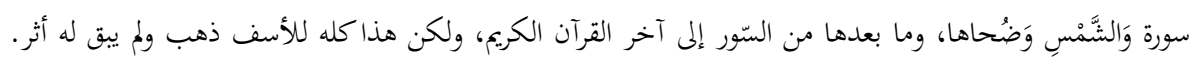

كانت الكتابة متوافرة في البيئة المكية والمدنية على حد سواء قبل الإسلام، وقد نبَّ لإلى هذه النقطة غير واحد

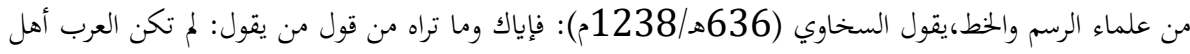

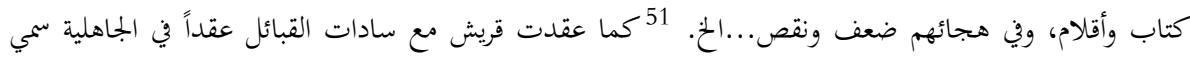

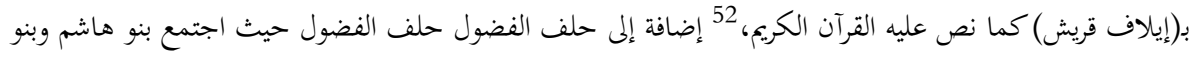

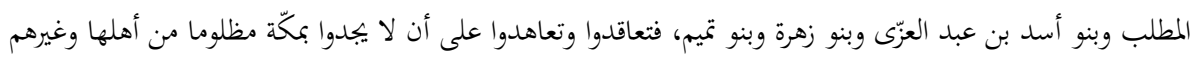

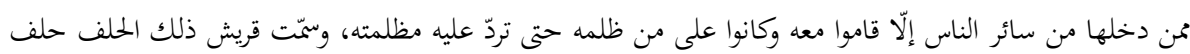

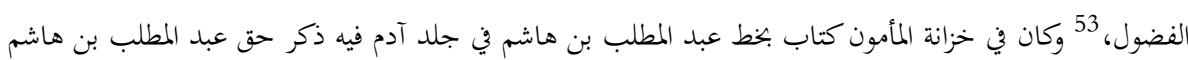

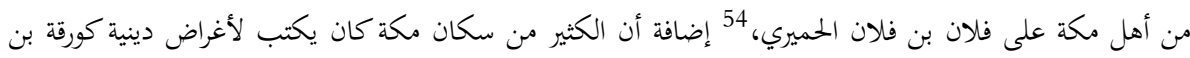

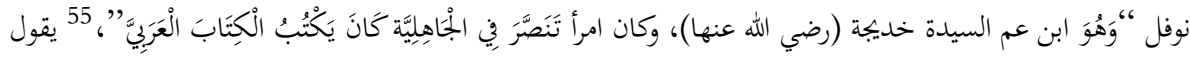

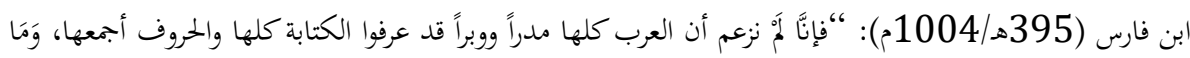

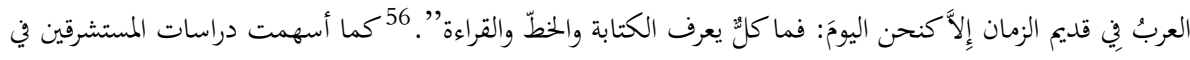

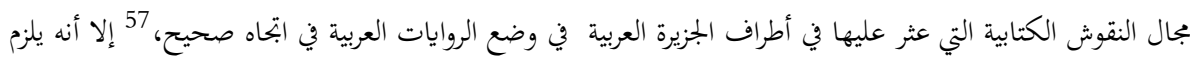

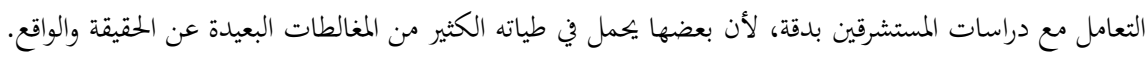

\section{الخاتمة}

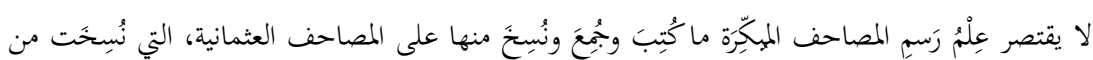

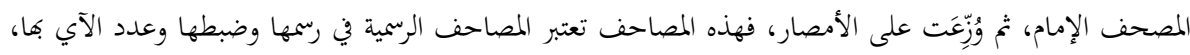
من جانب آخر، كان بين أيدي بعض كبار الصحابة مصاحف ورقوق كانت كمقتنيات خاصة بكم، كتبت بخطوطهم،

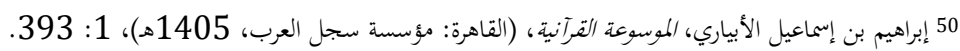

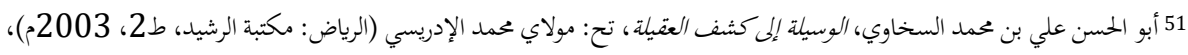

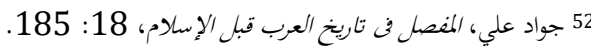

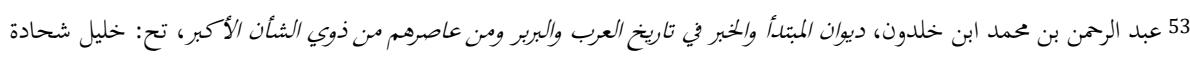

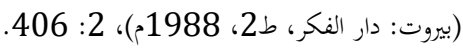

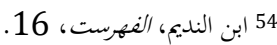

55 أبو الفرج عبد الرمن ابن الجوزي، المتنظم في تاريخ الأمم والموك، تح: حمد عطا، مصطفى عط (بيروت: دار الكتب العلمية، ط1،

1992م)، 2 : 350.

56 أممد بن فارس بن زكرياء الرازي ابن فارس، الصاحبي في فقه اللغة العربية ومسألها وسنن العرب في كلامها، تح: أمدد حسن بسبح

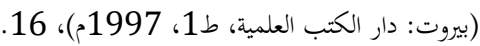

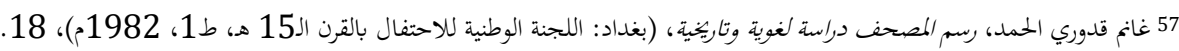


وكانوا يقرأون ويُّرِِون الناس بها، كمصحف عبد الله بن مسعود ومصحف عبد الله بن عباس وغيرهما. فعند البحث في

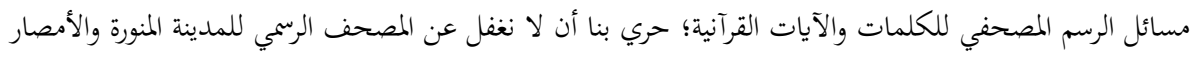

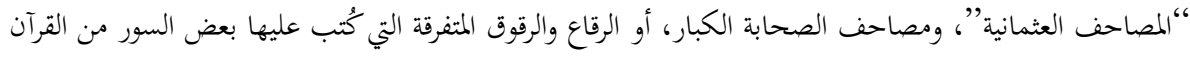

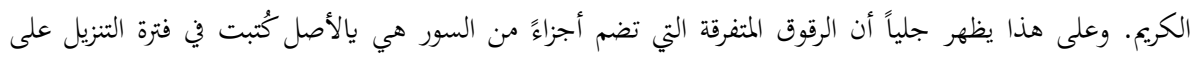

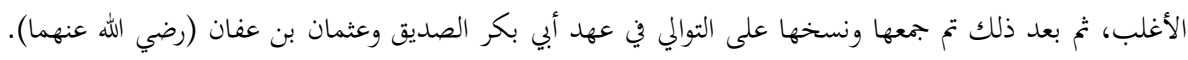

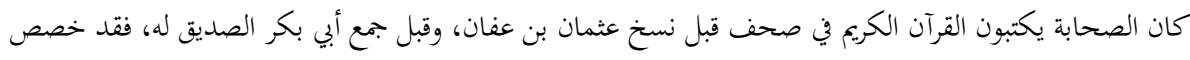

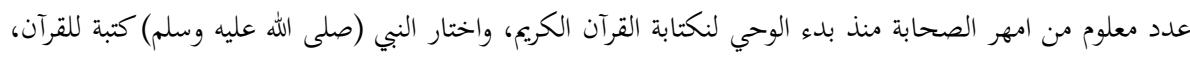

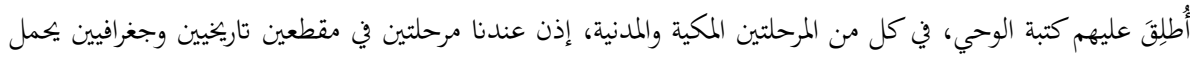

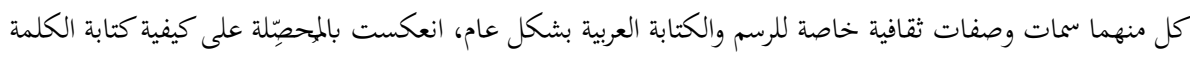

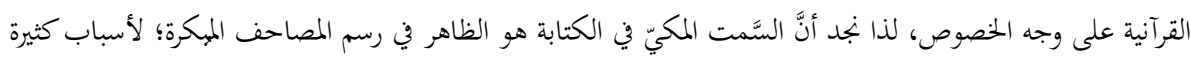

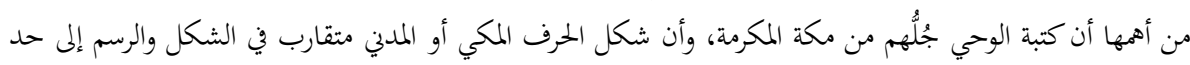

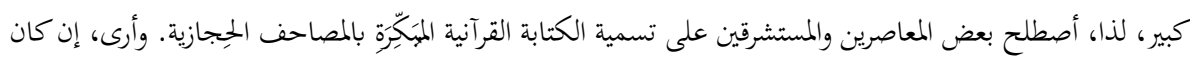

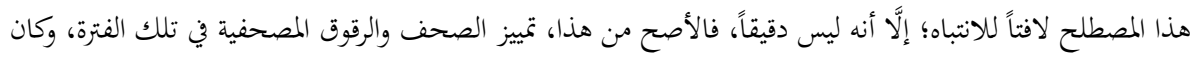

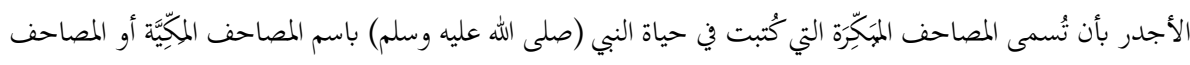

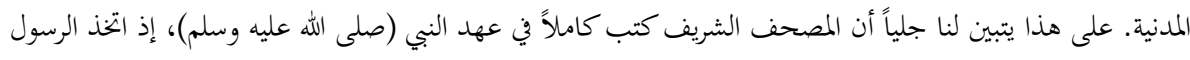

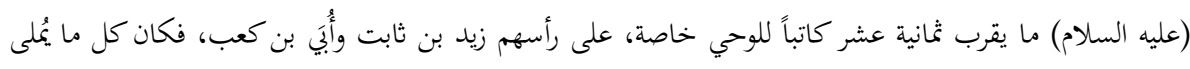

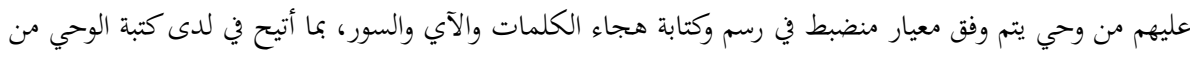

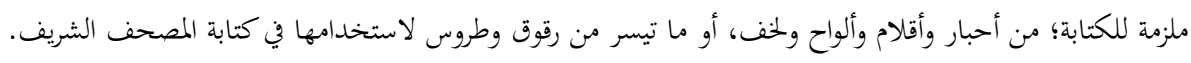

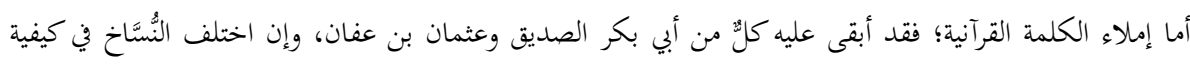

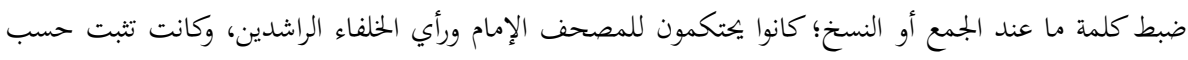

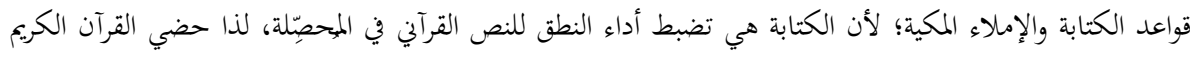

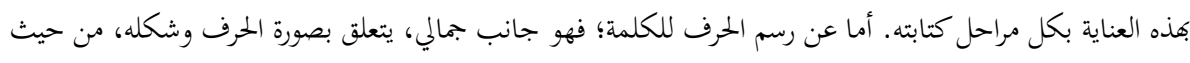

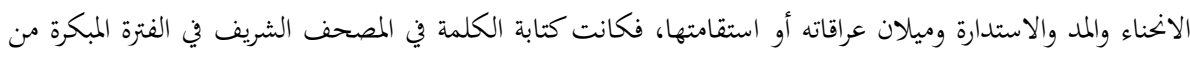

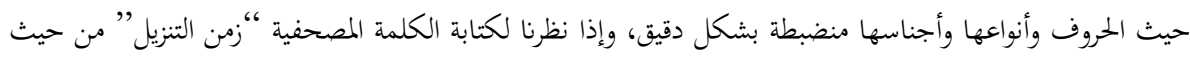

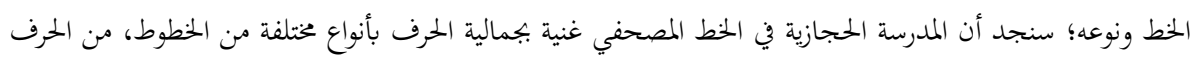

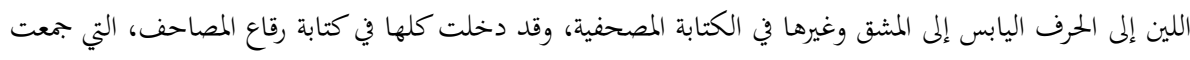

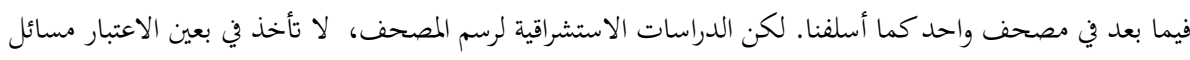

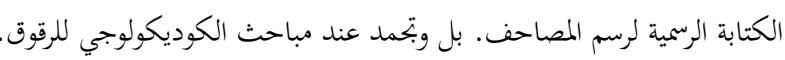

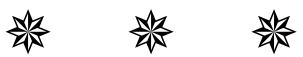




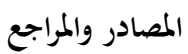

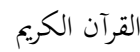

البَطَلْيْوسي، أبو محمد عبد الله بن محمد بن السِّيد. الاقتضاب في شرح أدب الكتاب. تح. مصطفى السقا وحامد عبد

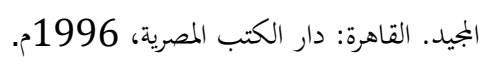

ابن الجوزي، أبو الفرج عبد الرمن. المنتظم في تاريخ الأمم والملوك. تح. محمد عطا، مصطفى عطا. بيروت: دار الكتب العلمية، ط1، 1992م.

ابن حميد، صالخ بن عبد الله. نضرة النعيم في مكارم أخلاق الرسول الكرمه، جدة: دار الوسيلة، ط4، د.ت. ابن خلدون، عبد الرمن بن محمد. ديوان المبتدأ والخبر في تاريخ العرب والبربر ومن عاصرهم من ذوي الشأن الأكبر.

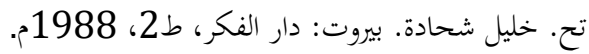

ابن عبد البر، يوسف بن عبد الله القرطب. الاستيعاب في معرفة الأصحاب. تح. علي البجاوي. بيروت: دار الجيل،

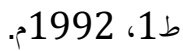

بن عساكر، أبو القاسم علي بن الحسن. تاريخ دمشق. تح. عمرو بن غرامة. دمشق: دار الفكر، 1995م. ابن فارس، أحمد بن فارس بن زكرياء الرازي. الصاحبي في فقه اللغة العربية ومسائلها وسنن العرب في كلامها. علق عليه

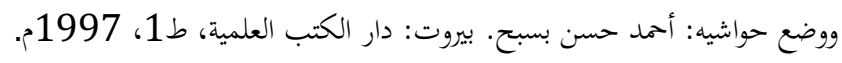
ابن النديم، أبو الفرج محمد بن إسحاق بن محمد الوراق. الفهرست. تحقيق: إبراهيم رمضان. بيروت: دار المعرفة، ط2، 1997

الأبياري، إبراهيم بن إسماعيل الأبياري. الموسوعة القرآنية. القاهرة: مؤسسة سجل العرب، 1405هـ. جواد علي. المفصل فى تاريخ العرب قبل الإسلام. لندن: دار الساقي، ط4، 2001م.

الحمد، غانم قدوري. رسم المصحف دراسة لغوية وتاريخية. بغداد: اللجنة الوطنية للاحتفال بالقرن ال15 ه، ط1، 1982

الداني، عثمان بن سعيد بن عثمان بن عمر أبو عمرو. المحكم في نقط المصاحف. تح. عزت حسن، دمشق: دار

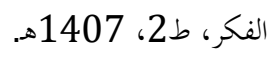

ــالمقنع في رسم مصاحف الأمصار. تح. محمد الصادق قمحاوي. القاهرة: مكتبة الكليات الأزهرية، د.ت. الرافعي، مصطفى صادق. تاريخ آداب العرب. بيروت: دار الكتاب العربي، د.ت.

زقزوق، محمود حمدي وآخرون. موسوعة المفاهيم الإسلامية العامة. القاهرة: المجلس الأعلى للشئون الإسلامية، 


$$
\begin{aligned}
& \text { السخاوي، أبو الحسن علي بن محمد. الوسيلة إلى كشف العقيلة. تح. مولاي محمد الإدريسي. الرياض: مكتبة الرشيد، }
\end{aligned}
$$

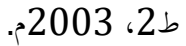

$$
\begin{aligned}
& \text { السالمي، نور الدين بن عبد الله. تحفة الأعيان بسيةة أهل عُعمان. مسقط: مكتبة الإمام السالمي، 2000م. } \\
& \text { السيابي، أحمد بن سعود. الوسيط في التاريخ العماني. مسقط: مكتبة الضامري، ط3، 2015م. } \\
& \text { السمعوني، طاهر بن صالخ بن أحمد الجزائري ثم الدمشقيّ. توجيه النظر إلى أصول الأثثر. تح. عبد الفتاح أبو غدة. } \\
& \text { حلب: مكتبة المطبوعات الإسلامية، ط1، 1995م. } \\
& \text { الصولي، أبو بكر محمد بن يحى. أدب الكتاب. بغداد: المكتبة العربية، 1341هـ. }
\end{aligned}
$$

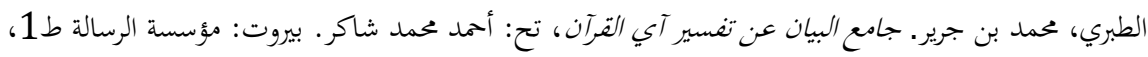

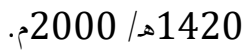

$$
\begin{aligned}
& \text { _- تاريخ الرسل والملوك. بيروت: دار التراث، ط2، 1387هـ. } \\
& \text { الطويل، رزق. مقدمة في أصول البحث العلمي وتعقيق التراث. القاهرة: المكتبة الأزهرية للتراث، ط2، د.ت. } \\
& \text { القِنَّجي، أبو الطيب عممد صديق خان الحسيني البخاري. أبيد العلوم. عمان: دار اين حزم، ط1، 2002م. } \\
& \text { الكرماني، أبو القاسم محمود بن مززة تاج القراء. خط المصاحف. تح. غانم قدوري الحمد، المنامة: طبعة خاصة لجائزة }
\end{aligned}
$$

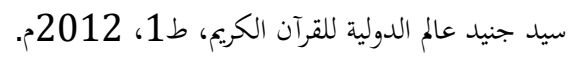

$$
\begin{aligned}
& \text { النقشبندي، ناصر. “منشأ الخط العربي وتطوره لغاية عهد الخلفاء الراشدين”. بجلة سومر.1/جلد3. بغداد: نشريات } \\
& \text { سومر، 1947م. } \\
& \text { الهاشي، أممد بن إبراهيم. جواهر الأدب في أدبيات وإنشاء لغة العرب. تح. بجموعة حققين. بيروت: مؤسسة }
\end{aligned}
$$

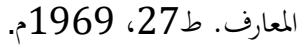

$$
\begin{aligned}
& \text { الهروي، أبو عُبيد القاسم بن سلاّم بن عبد الله البغدادي. فضائل القرآن. تح. مروان العطية وآخرون، دمشق: دار ابن }
\end{aligned}
$$

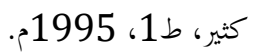

$$
\begin{aligned}
& \text { المصاحف المخطوطة }
\end{aligned}
$$

Adbury Research Library .University of Birmingham. Islamic Arabic 1572,

(Birmingham, GB) -004:129- 22-30 Zeilen.

Șan'a, Dār al-mahțūțāt. Haus der Handschriften. (Șan'a, YE): DAM 01-27.

Berlin, Staatsbibliothek: Kodex Samarkand (Sankt Petersburg 1905):

(Berlin, DE) -002. 
الكتابة الحجازية للمصحف الشريف في صدر الإسلام

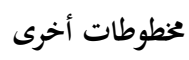

\section{El yazmaları}

İbnü'n Nedîm, Ebü'l-Ferec Muhammed b. Ebî Ya'kūb İshâk b. Muhammed b. İshâk. el-Fihrist, İstanbul: Süleymaniye Kütüphanesi, Fażıl Aḥmed Paşa, 1134.

İbnü'n Nedîm, Ebü'l-Ferec Muhammed b. Ebî Ya'kūb İshâk b. Muhammed b. İshâk. el-Fihrist, İstanbul: Süleymaniye Kütüphanesi, Fażıl Ahmed Pașa, 1135.

İbnü'n Nedîm, Ebü'l-Ferec Muhammed b. Ebî Ya'kūb İshâk b. Muhammed b. İshâk. el-Fihrist, Fransa: Milli Kütüphanesi, btv 1b110038486.

المصادر الإلكترونية

\section{Web Sayfa Başlığı}

Adbury Research Library, "University of Birmingham”. Erişim 1 Ocak 2020.

Șan'a, “Dār al-mahțūțāt”, Erişim 11 Ocak 2020.

Berlin, "Staatsbibliothek", Erişim 5 Ocak 2020.

Adbury Research Library “University of Birmingham”, Erişim 1 Mayıs 2020.

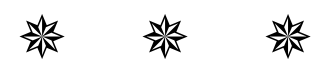




\title{
İSLÂM'IN İLK DÖNEMİNDE MUSHAF-I ŞERİF'İN ḤíCÂZî YAZISI
}

\begin{abstract}
Geniş Öz
Arap Yarımadası çevresinde bulunan Arap hattının tarihi ve gelişiminin aşamalarını şu şekilde değerlendirmek mümkündür: İlk olarak Hiicaz'da (Mekke-i Mükerreme ve Medine-i Münevvere) Kur'ân-ı Kerim'in yazıldığı Arap hattının incelenmesi üzerinedir. Bu aşama, bizi İslam'ın erken dönemlerine Kur'ân-ı Kerim'in yazılma tarihini incelemeye götürür. Şöyle ki; Kur'ân-ı Kerim hattı iki aşamaya şahit olmuştur: Birincisi, Hz. Peygamber (s.a.v) zamanındaki yazma aşaması ve ikinci olarak da Râşid halîfeler döneminde gerçekleşen toplama ve çoğaltma sürecidir.

Vahiy aşamasına gelince, Hz. Peygamber (s.a.v) vahyi yazmak için okuma ve yazma konusunda en yetenekli sahâbîleri seçmiştir. Ancak üzerinde durulması gereken önemli bir konu ise, Hz. Ebû Bekir ve Hz. Osman döneminde Kuran'ın toplanıp çoğaltılmasından önce Hz. Peygamber zamanında harflerin ve sahifelerin hususiyetlerinin tespiti üzerinedir. $\mathrm{Bu}$ araştırma mezkûr konuyu araştırmayı hedeflemektedir. Çalışma aynı zamanda şu soruları da cevaplamaya çalışmaktadır: Kur'ân-ı Kerim'in yazıldığı Kufi yazı türünden önce herhangi bir yazı türü var mıydı? Kuran-ı Kerim'in Mekke'deki yazma özellikleri ile Medine'deki yazma özellikleri aynı mıydı, Kur'ân-ı Kerim'in iki hat ile (Ḥicazî ve Kûfî) yazılmasının ayırt edici özellikleri ve meziyetleri nelerdir?

Erken dönem Mushaf konusunu ele alan en önemli kaynaklar, referanslar ve araştırmalara nazaran, Müslüman âlimlerin tarih boyunca bu meseleye ayrıca ilgi gösterdiklerini ve bu mesele hakkında çeşitli yazılar yazdıkları görülmektedir.Fakat ilk dönemlerde yazılanların büyük bir kısmının
\end{abstract}

\footnotetext{
a Doç. Dr., İstanbul Üniversitesi, guller_guler@yahoo.com

b Doktora Öğrencisi, İstanbul Üniversitesi, khadeejeh.alrawashdeh@istanbul.edu.tr
} 
kaybolduğunu ve geriye kalanların ise hicrî üçüncü yüzyıldan sonraya ait olduğuna şahit olmaktayız.Müstakil olmaksızın Kur'ân-ı Kerim resmini(formunu) ele alan en önemli kaynaklar arasında şunlar bulunmaktadır: İbnü'n-Nedîm'in (ö.384/994) “el-Fihrist"i; Ebu Hayyân etTevhîdî'nin (ö. 414/1023) "Risâletûn fi 'ilmi'l-kitâbe"adlı eserlerdir. Kur'ân'ınşekil açısından tarihi sürecini ele alan kaynaklar arasında ise;Ebû 1Abbâs el-Mehdevî'nin (ö. 440/1048) "Hicâ'ûmeșâhifi'-emșâr", İbnMuâz elCühenî̀nin (ö.442/1050"el-Bedî̀", Ebû Amred-Dânî”nin (ö.444/1052) "elMuḲnî́ fî m'arifeti mersûmi meșâhifiehli'l-emșâr", Kirmânî'nin (ö.500/1106) "Hațțu'l-mâhif", Şâtıbînin (ö.590/1194) “Akīletüetrâbi'l-Kașâid", YûsufelKâydî el-Hârizmî'nin (ö.618/1221) "Hicâ'l-meșâhîif”, ve Harrâz'ın (ö.718/1318) “Mevridü'z-zִam'ân fi resmi ahrûfi'l-Kur'ân” bulunmaktadır.

Ayrıca günümüzde de birtakım çalışmalar bulunmaktadır. Bu araştırmalar, İslam'ın değişik alanlarında ve Kur'ân ilimlerinde mütehassıs kişiler tarafından yapılmıştır. Bu alanda çalışanların en önemlileri arasında yer alan Prof. Dr. Tayyar Altıkulaç, Hz. Osman'a nispet edilen Mushaf-ı Şerif nüshalarının tahkiki ve neşrinde ciddi bir şekilde yoğunlaşmıştır. Topkapı Sarayı Müzesi nüshası, Șan'a nüshası, Türk ve İslam Eserleri Müzesi nüshası, el-Meşhedü'l Hüseynî nüshası, ilaveten Hz. Ali'ye nispet edilen Tahran nüshası başlıca eserleridir. Yine muasır uzmanlardan Prof. Dr. Ganim Kuduri elHamd bütün çalışmalarında ve araştırmalarında bu alana yoğunlaşmıştır. 'Ulûmü'l-Kur'ân beyne'Imeșâdiri ve'l-meșâhîf" ve "meșâhîf-i mahtūṭe" kitapları bu alandaki en önemli eserlerindendir.

Öte yandan Oryantalistler de Mushaf-ı Şerif'in tarihine ihtimam göstermişlerdir. Bunlardan en meşhur olanı, "Kur'an Tarihi" adlı kitabıyla Alman şarkiyatçı TheodorNöldeke'ye (ö.1348/1930) aittir. Daha sonra ise şarkiyatçı AntonSpitaler tarih boyunca Kur'an-ı Kerim'in el yazmalarını ve nadir olan görüntülerin arşivini oluşturmuștur. AntonSpitaler bunu daha sonraları II. Dünya savaşında İngiliz uçakları tarafından yok edilecek olan Bavyera Bilim Enstitüsüne bağlı olan özel bir akademi bünyesinde kurmuştu. Anton Spitaler arşivin bu nedenle kaybolduğunu iddia ediyordu. Bunun aksi olduğunu göstermek, arşivi yeniden açığa çlkarmak gayesiyle18 yll sürecek olan Alman hükümeti finansmanıla Corpus Coranicum adlı projeyi başlatmak için Angelika Neuwirth ve Michael Marx harekete geçtiler. 2007 senesinde başlayan bu proje dünyanın farklı ülkelerinden çalışma gruplariyla halen devam etmektedir. Bu nedenle projeye Corpus Coranicum ismini verdiler. $\mathrm{Bu}$ isimlendirmenin ideolojik bir görüntüsü vardır. Çünkü onlar bu isimlendirmeyle hakikatte araştırmanın ön sonuçlarını göz önüne 
sererek, neticeyi ise çalışmayı bitirmeden vermişlerdir.

Erken Mushaf meselesinin tarihi ve sanatıyla ilgilenen Oryantalistler'e de rastlamak mümkündür. Bu sahada"The Rise of the North Arabic Script and Its Kur 'änic Development, with a Full Description of the Kur 'än Manuscripts in the Oriental Institute" adlı eseriyle Amerikalı araştırmacı Nabia Abbott (ö.1357/1939) ve yine Amerikalı araştırmacı EstelleWhelan'ın (ö.1417/1997) “Writing the Word of God: Some Early Qur'ān Manuscripts and Their Milieux, Part I" adlı eserleri zikredilmeye değerdir. Araştırmacı EstelleWhelan'ın bu eseri Medine'de hicrî birinci yüzyılda Kuran-ı Kerim'i kaydedilme sanatını kanıtlamak için "unutulmuş tanık" çalışmasıdır. Bu ifadeyle nakışlar ve Emevîmushaf yazıları kastedilir.

Yine Oryantalistlerden Sheila S. Blair'in "İslamic Calligraphy" isimli eseri ve François Deroche'nin "The Abbasid Tradition" eseribu alan içerisinde sayılmaktadır. 1992 yılında yayınlanan François Deroche'ninbu eseri, Mushaf-ı Şerif' in Hicazîve Abbasî yazı türüyle yazılmasını ele alır. İkincisi ise 2014 senesinde yayınlanan "Qur'ans of the Umayyads" adlı eseridir. Emeviler döneminde Mushaf-ı Şerif'in şekli ve zaptı gibi başlıca konuları ele alan bir eserdir. Ayrıca David J. Roxburgh'un 2007 yılında yazdığı "Writing the word of God" adlı eseri de öne çıkanlardandır. Çalışmada değineceğimiz üzere Oryantalist araştırmalar, Kuran-ı Kerim'in fenni yönlerini ortaya koymanın yanında ideolojik birtakım değerlendirmelerde de bulunmuşlardır.

Bu çalışmanın amacı; Mushaf-ı Şerif'in erken dönem tavsifi çalışmasıbilimsel tarih yazımı yöntemine dayanarak Paleografi, İktina, Kodikoloji, Kitap bilimi, Sanat ve Süsleme türleri, Mürekkep türleri ve Hat çeșitleri gibi ilimleri hicri ikinci yüzyıldaki mușhafların nasıl yazıldığını icra etmektedir. Bu kullanılan ilimler bize kadim el yazmalarında şarkiyatçıların yalnızca bir incelemeye tabi tutmalarının (c14) aksine Müslüman alimlerin belirlediği yöntemler ile daha dakik ve daha isabetli malumatlar verecektir.

Anahtar Kelimeler: Mushaf-ı Şerif, Mekkî hattı, Vahiy Kâtibi, Medenî hattı, İbnü'n-Nedîm. 


\title{
THE HIGAZI SCRIPTURE OF THE HOLY MANUSCRIPT IN THE EARLY TIMES OF ISLAM
}

\author{
Ziyad ALRAWASHDEH ${ }^{\mathrm{a}}$
}

Khadeejeh ALRAWASHDEH ${ }^{b}$

\section{Extended Abstract}

A research on the history and development of Arabic manuscripts around the Arabian Peninsula is considered the first step towards Arabic calligraphy work used in the writing of the Mushaf Al-Sharif in the Hejaz (Makkah AlMukarramah and Madinah Al-Munawwarah). This leads us to study the history of the writing of the Mushaf Al-Sharif based on the first period of Islam, as the writing of the Mushaf witnessed two stages: the writing stage during the time of the Prophet (saw), and its compilation and calligraphic stage during the time of the Khulafa Ar-Rashidun (the Rightly Guided Caliphs). During the revelation stage, the Prophet (saw) chose his most proficient Companions in reading and writing as scribes of the revelation. The research question is concerned with the alphabet and the quality of the manuscripts which were written during the period of the Prophet (saw), before their compilation and calligraphic work during the time Abu Bakr AsSiddiq and Uthman ibn Affan (May Allah be pleased with them). The research also seeks to answer following questions: Was there another calligraphic style for the Mushaf Al-Sharif before the Kufic script used in the Mushaf AlSharif? Are the features of the manuscripts in Makka Al-Mukarramah the same as the ones of the manuscripts in Madinah Al-Munawwarah? What are the similarities and differences between the Hijazi script or Kufic script in the Mushaf Al-Sharif?

Analyses on the most important sources, testimonials and works on early period manuscripts show that throughout history Muslims scholars attached great importance to the issue and wrote about it. However, most of the writings from the early centuries are remnants from after the 3rd Hijri

a Assoc. Prof., İstanbul University, guller_guler@yahoo.com

b PhD. Student, İstanbul University, khadeejeh.alrawashdeh@istanbul.edu.tr 
century. The most important sources, which dealt with the script of the Mushaf Al-Sharif independently are as follows: Ibn al-Nadim's work, titled "Kitab al-Fihrist" (H. 384/994 A.D.), and Abu Hayyan al-Tawhidi's work, titled "Risala fi 'ilm al-Kitaba" (Treatise about Calligraphy) (H. 414/1023 A.D.). Sources dealing with the history of the Mushaf Al-Sharif are the following: Abu Abbas Al-Mahdawi's work, titled "Hajau Masahifi al-Amsar" (H. 440/1048 A.D.); Abu Omar al-Dani's work "Al-Mukni fi Marifeti Marsumi Masahifi al-Amsar" (H. 444/1052 A.D.); Al-Kirmani's "Had al-Masafih" (H. 500/1106 A.D.); Imam al-Shatibi's "'Aqilat al-Atrab" (H. 590/1193 A.D.); Yusuf al-Qaydi al-Khwarizmi's "Hajau al-Masahif" (H. 618/1221 A.D.); and the work, titled "Mawrid al-Zaman fi Rasmi Ahruf al-Qur'an" by Al-Kharraz (H. 718/1318 A.D.).

There also exist contemporary testimonials from experts on Islamic and Qur'anic research. One of the most important and most renowned personalities in this field today is Prof. Dr. Tayyar Altıkulaç, who conducted very important work on the analyses of the Qur'anic manuscripts (masahif) attributed to the great Companion Uthman ibn Affan (ra), including the Topkapi manuscript, the Șan'a manuscript, the manuscript in the Museum of Turkish and Islamic Arts, and the Al-Mashad al-Husseini manuscript. He also worked on the manuscript attributed to the great Companion Ali bin Abu Talib (ra), which is in Teheran. Prof. Dr. Ghanim Qadduri al-Hamad is another one among contemporary experts, who dedicated all his efforts on the research of this issue. His books, "Qur'anic Sciences in Sources and Manuscripts", and "Handwritten Masahif" are some examples of his work.

Also Orientalists were interested in the history of the Mushaf Al-Sharif. The most important work in this field is the book of Theodor Nöldeke $(\mathrm{H}$. 1348/1930 A.D.) titled, "The History of Qur'an". Then comes the orientalist, Anton Spitaler, who worked on this field and accumulated an archive of rare manuscripts and historical pieces within the Bavarian Academy of Sciences and Humanities, which was destroyed during World War II in 1944 through British air bombing. Anton Spitaler claimed that the archive was lost due to this. However Michael Marx and Angelika Neuwirth proved the opposite and started to restore the archive in 2007, with a 18-year financial support of the German government, which is called the Project "Corpus Coranicum". The project is conducted in teamwork of researchers from various countries. The aim of the project is to declare the influence of the Qur'an and the revelation upon the West. So they called their project "Corpus Coranicum", which is an |638| ideological name, which reveals their aim to prioritize their views over the results of the preliminary study, and to make conclusions even before 
completing the research.

The following Orientalist are among those who are most interested in early period Masahif, their history and calligraphic artwork: American researcher Nabia Abbott (H. 1357/1939 A.D.), with her book "The Rise of the North Arabic Script and Its Qur'anic Development with a Full Description of the Qur'an Manuscripts in the Oriental Institute"; and American Researcher Estelle Whelan's (H. 1417/ 1997 A.D.) work "Writing the Word of God: Some Early Qur'an Manuscripts and Their Milieux, Part 1", who describes it as a "lost witness" and focusses on the "Calligraphy and Illumination in the Mushaf al-Sharif of the Umayyads" in order to highlight the codification in Madinah Al-Munawwarah during the first century of Hijrah. Other Orientalist are Sheila S. Blair, author of the book "Islamic Calligraphy", and François Déroche, who elucidates Hijazi and Abbasid calligraphy in the Mushaf alSharif, in his book "The Abbasid Tradition", in 1992. Another book of the same author is the "Qur'an of the Umayyads" published in 2014, which describes the formation and the use of vowels in the Masahif of the Umayyad period. David J. Roxburgh is another Orientalist and author of the book, "Writing The Word of God" (H. 1428/2007 A.D.).

Alongside presenting the artistic aspects of the Masahif, these orientalist studies contain an ideological aspect too. This research will expand on this in the following chapters. The aim of this research is to describe the Mushaf AlSharif (early period Masahif), reveal their writing systems in the Hijri I. Century, using an academic chronology method, like "Paleography and Codicology", as well as the used calligraphy and illumination artworks, inks and fonts. This research will give detailed and more accurate insight to the issue, dwell on the analysis and radiocarbon dating (Carbon-14 dating) of some Orientalists, and expound on the manuscripts of the Mushaf Al-Sharif, which is a generally neglected topic.

Keywords: Mushaf Al-Sharif, Mekkan calligraphy, scribes of the revelation, Medinan calligraphy, Ibn al-Nadim.

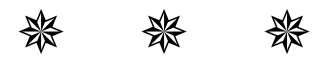

